\title{
CORONAVIRUS
}

Cite as: B. F. Haynes et al., Sci. Transl. Med. 10.1126/scitranslmed.abe0948 (2020).

\section{Prospects for a safe COVID-19 vaccine}

\author{
Barton F. Haynes ${ }^{*}$, Lawrence Corey ${ }^{2}$, Prabhavathi Fernandes ${ }^{3}$, Peter B. Gilbert ${ }^{4}$, Peter J. Hotez ${ }^{5}$, Srinivas Rao ${ }^{6}$, \\ Michael R. Santos ${ }^{7}$, Hanneke Schuitemaker ${ }^{8}$, Michael Watson ${ }^{9}$ and Ann Arvin ${ }^{10}$ \\ ${ }^{1}$ Duke Human Vaccine Institute, Duke University School of Medicine, Durham, NC 27710, USA; ${ }^{2}$ Vaccine and Infectious Disease Division, Fred Hutchinson Cancer Research \\ Center, University of Washington, Seattle, WA 98109, USA; ${ }^{3}$ Global Antibiotic Research \& Development Partnership (GARDP), Geneva, Switzerland; ${ }^{4}$ Vaccine and Infectious \\ Disease Division, Fred Hutchinson Cancer Research, Washington, Seattle, WA 98109, USA; ${ }^{5}$ Texas Children's Center for Vaccine Development, National School of Tropical \\ Medicine, Baylor College of Medicine, Houston, TX 77030, USA; ${ }^{5}$ Sanofi Research and Development, Sanofi North America, Cambridge, MA 02142, USA; ${ }^{7}$ Foundation for the \\ National Institutes of Health, North Bethesda, MD 20852, USA; ${ }^{8}$ Janssen Vaccines \& Prevention B.V., Leiden, Netherlands; ${ }^{9}$ Moderna, Inc., Cambridge, MA 02139, USA; \\ ${ }^{10}$ Departments of Pediatrics and Microbiology and Immunology, Stanford University School of Medicine, Stanford, CA, 94305, USA \\ *Corresponding author. Email: Barton F. Haynes barton.haynes@duke.edu
}

Rapid development of an efficacious vaccine against the viral pathogen SARS-CoV-2, the cause of the coronavirus disease-2019 (COVID-19) pandemic, is essential, but rigorous studies are required to determine the safety of candidate vaccines. Here, on behalf of the Accelerating COVID-19 Therapeutic Interventions and Vaccines (ACTIV) Working Group, we evaluate research on the potential risk of immune enhancement of disease by vaccines and viral infections, including coronavirus infections, together with emerging data about COVID-19 disease. Vaccine-associated enhanced disease has been rarely encountered with existing vaccines or viral infections. Although animal models of SARS-CoV-2 infection may elucidate mechanisms of immune protection, we need observations of enhanced disease in people receiving candidate COVID-19 vaccines to understand the risk of immune enhancement of disease. Neither principles of immunity nor preclinical studies provide a basis for prioritizing among the COVID-19 vaccine candidates with respect to safety at this time. Rigorous clinical trial design and post-licensure surveillance should provide a reliable strategy to identify adverse events, including the potential for enhanced severity of COVID-19 disease, following vaccination.

\section{INTRODUCTION}

The new human viral pathogen, severe acute respiratory syndrome-coronavirus-2 (SARS-CoV-2), the cause of the coronavirus disease 2019 (COVID-19) pandemic, emerged in $\mathrm{Wu}-$ han, China in late 2019. The global COVID-19 pandemic continues to expand in many countries including the United States. A protective vaccine will be required to achieve sufficient herd immunity to SARS-CoV-2 infection to ultimately control the COVID-19 pandemic (1). The World Health Organisation (WHO) has listed more than 200 COVID-19 vaccines as under development (2), and expectations for effective prophylactic COVID-19 vaccines are high. The hope that preventive vaccines will control COVID-19 is justified by the impact of vaccines on preventing disability and death from other infectious diseases. (3). Vaccines against infectious diseases are estimated to have saved at least 23 million lives between 2011 and 2020 (4).

An essential part of developing any vaccine is to ensure that known and theoretical safety risks are identified, quantified and weighed against potential benefits. Among the potential risks raised in the context of COVID-19 vaccine development is whether the immune responses elicited by a vaccine could enhance SARS-CoV-2 acquisition or make the disease worse when infection occurs after vaccination. Recent commentaries have provided background and assessments of aspects of this question as it relates to COVID-19 vaccines (1, 5-9). Here, we review the relevant literature and evaluate the possibility of enhanced disease caused by COVID-19 vaccines.

For this Review, we define immune-associated enhanced disease as an infection that is made worse because the person has a pre-existing immune response against the pathogen. Vaccine-associated enhanced disease (VAED) is defined as an immune response to a vaccine that is causally linked to a higher risk of adverse outcomes upon infection compared to infection without prior vaccination. Pathogen-specific antibodies have been associated with disease enhancement, called antibody-dependent enhancement (ADE), in rare cases of secondary dengue infection (6-8). VAED was observed in children given formalin-inactivated whole virus vaccines against respiratory syncytial virus (RSV) and measles virus in the 1960s. Here, we assess in vitro data, animal model data and human data relevant to forms of VAED to provide background for vaccine scientists and developers, health-care providers, policymakers and public health advocates. 
IMIMUNE ENHANCEMENT OF VIRAL INFECTIONS AFTER VACCINATION OR NATURAL INFECTION

RSV is the leading cause of bronchiolitis and pneumonia in the first 1-2 years of life and is also a cause of severe respiratory illness in older persons. VAED was observed when a formalin-inactivated vaccine for RSV (FI-RSV) was given to infants and young children in clinical trials in the 1960s (1-3, 5, 10-12) (Fig. 1). In these studies, the overall incidence of RSV infection was not increased when compared to either an unimmunized or a formalin-inactivated parainfluenza vaccinated group (FI-PV) $(11,12)$. However, hospitalization rates for severe RSV were higher in children vaccinated with FIRSV from 6-11 months of age, with two fatal cases in this age group, and, to a lesser extent, in those immunized at 12-23 months of age, but not in children vaccinated at $>2$ years. These age-associated differences indicated that the risk was highest in infants with an immature immune system or when FI-RSV was administered before the child's first encounter with RSV. Notably, parainfluenza virus hospitalizations were not increased among children given FI-PV, despite formalin inactivation of the vaccine (11).

The FI-RSV studies were terminated because of VAED, but specific characteristics of FI-RSV induced immunity were not established as causative. RSV neutralizing antibodies are primarily directed against the fusion protein that exists in a metastable pre-fusion conformation prior to virus entry into host cells, which changes to a post-fusion form upon host cell receptor engagement. The post-fusion state is the predominant conformation after formalin inactivation (13). In the FI-RSV clinical trials, neutralizing antibodies were induced by the vaccine in fewer children $(43 \% ; 10 / 23)$ than after natural infection $(75 \%$; 12/16) (12). Although 14 of 15 vaccinees who developed RSV disease had neutralizing antibodies at the onset of illness (12), later studies indicated that vaccinees had a higher ratio of fusion protein binding antibodies than RSV neutralizing antibodies compared to controls with natural RSV infection (14). Later animal studies also showed that the FI-RSV lot used in the clinical studies failed to elicit neutralizing antibodies in cotton rats and that the animals developed more severe lung pathology upon RSV challenge than did mock vaccinated animals (15). However, understanding immunological correlates of protection in the vaccinated children was limited because the only assay to measure $\mathrm{T}$ cell immunity was lymphocyte transformation, which did not allow the assessment of antigen specificity, cytokine profiles or cytotoxic functions of T cells induced by FI-RSV. Pathologically, the two infants with fatal infections had severe alveolitis with neutrophilic and lymphocytic infiltrates and peribronchial inflammation (16) as well as evidence of immune complex formation in lung tissues (17). Potential mechanisms of VAED suggested by these studies of children given the FIRSV vaccine include antibodies directed against non- protective fusion protein epitopes, a failure to elicit highavidity neutralizing antibodies to RSV fusion protein, aberrant antibody responses to other RSV proteins, activation of the complement pathway by immune complex deposition, and abnormal $\mathrm{T}$ cell responses (Fig. 1). Animal model studies support other potential factors including a bias toward $\mathrm{T}$ helper type 2 (Th2) cell cytokine responses, a lack of antibody affinity maturation that may occur in young children due to several putative mechanisms including poor Toll-like receptor stimulation (18), insufficient regulatory $\mathrm{T}$ cell activity and poor priming of cytotoxic T cells (19). Without a defined mechanism for VAED due to FI-RSV, the recent Vaccines and Related Biological Products Advisory Committee report concluded: "In the absence of a reliable method for differentiating between enhanced respiratory disease and severe RSV infection, identification of possible vaccine-associated enhanced respiratory disease will likely rest on detecting a significant difference in rates of severe RSV disease between vaccine and control groups" (19).

A formalin-inactivated measles virus vaccine licensed in the 1960s was withdrawn because some immunized children developed atypical measles with high fever, an unusual petechial/papular rash and atypical pneumonia (20). Measles neutralizing antibodies persisted in only $25 \%$ of immunized children at one year of age, and 8 of 125 vaccinees developed atypical measles after a known exposure two or more years later (20). When live attenuated measles virus was given after formalin-inactivated measles virus, papular lesions that showed immune complex deposition appeared at the inoculation site. In contrast, the live attenuated measles virus vaccine has high protective efficacy with no enhanced disease (21).

Dengue infections are caused by one of the four related dengue virus serotypes. Rarely, these viruses cause dengue hemorrhagic fever/shock syndrome, which can occur with primary infection but also when a person who had a prior infection becomes infected with another serotype (22). Although immunity from a previous infection can provide protection, enhancement of disease severity under these circumstances has been suggested to be mediated by ADE, based on in vitro observations. In cell culture, antibodies against dengue virus that bind to virus particles and cells of the immune system (macrophages, monocytes or dendritic cells) that express receptors for the Fc portion of the antibody provide an alternate pathway for virus entry, in addition to binding and entry via the specific viral receptor (Fig. 1). Whereas antibody-mediated entry of host cells results in destruction of most viruses, dengue viruses can replicate after entry through this pathway. Thus, ADE of dengue disease can occur during a second infection with a different virus serotype due to cross-reactive antibodies with suboptimal neutralizing capacity against the newly incoming virus, in 
combination with the Fc-mediated targeting of immune cells by the virus. ADE of dengue disease has been reported to have a $0.5 \%$ attack rate $(36 / 6684)$ where it was associated with a narrow range of neutralizing antibody titers (1:20-1:80) at the time of infection (23).

A potential enhancing effect of pre-existing dengue antibodies was also raised as a concern in clinical trials of the quadrivalent live-attenuated dengue vaccine, Dengvaxia (Sanofi Pasteur), where immunization of dengue-naïve 2-8 year old children correlated with a lower risk of severe disease for two years, but subsequent hospitalization rates were higher in vaccinees than placebo recipients in the third year (24). It was not established whether the higher hospitalization rates resulted from an undefined age-related factor, failure to protect against infection with particular serotypes, cross-reactive antibodies, limited cell-mediated immunity, or a combination of factors. Post-licensure, 15 deaths from dengue disease were reported in 9-13 year old children in the Philippines (where $>830,000$ children received one dose and $>365,000$ received all three doses) and 14 of the deaths were investigated by the WHO Global Advisory Committee on Vaccine Safety. Their conclusion was that individual cases could not be attributed to vaccine failure or vaccine-related immune enhancement because there were no criteria to differentiate the two (25). Based on protective efficacy, Dengvaxia is now recommended for dengue seropositive individuals $>9$ years old where dengue is prevalent.

\section{EXPERIENCE WITH OTHER VIRAL INFECTIONS AND VIRAL VACCINES}

Despite the high antigenic diversity and prevalence of influenza viruses, extensive annual surveillance has not revealed correlations between more severe illnesses and preexisting immunity. When an antigenic shift caused the 2009 H1N1 pandemic, a cohort of middle-aged patients was reported to have low avidity antibodies against the H1N1-2009 virus, and six people in this age group with fatal pneumonia had evidence of pulmonary immune complex formation (26). Thus, decades of surveillance suggest that immune enhancement of natural influenza virus infection is rare despite the prevalence of cross-reactive antibodies with limited neutralizing activity. In addition, influenza immunization programs demonstrate that inactivated vaccines per se do not potentiate the risk of VAED, even though vaccine antigens used to induce immunity may not be matched to the influenza viruses that emerge (27). Whereas some epidemiological studies of the 2009 H1N1 pandemic reported more medically attended illnesses among vaccinated people (28), others supported vaccine efficacy $(26,29)$, partial protection, or infection but without evidence of VAED (30).

Although cross-reactive antibodies to parainfluenza viruses 1,2 and 3 are elicited and the same individual is typically infected with the other virus serotypes over time, pre-existing immunity is not known to result in severe disease due to a different parainfluenza virus serotype.

Infection by different rotavirus serotypes is another example of a circumstance where cross-reactive immunity typically provides some protection and does not potentiate disease. Inactivated vaccines, such as the polio vaccine, may induce less potent neutralizing antibodies against one or more viral serotypes, but VAED has not been reported. Thus, vaccines made from inactivated viruses do not have an intrinsic potential to elicit deleterious immune responses.

\section{IMMUUNE ENHANCEMENT OF DISEASE IN ANIMAL MODELS OF HUIMAN CORONAVIRUSES}

The outbreak of Severe Acute Respiratory Syndrome (SARS) caused by the SARS-CoV-1 coronavirus emerged in Southern China in 2002, and the Middle Eastern Respiratory Syndrome (MERS) outbreak caused by MERS-CoV was first reported in Saudi Arabia in 2012. Although multiple animal models of SARS-CoV-1 and MERS-CoV infection and of the related coronavirus SARS-CoV-2 have been developed, they do not fully recapitulate the pathology or clinical symptoms of severe coronavirus infections in humans. Some elements similar to human pulmonary disease can be observed in mice, hamsters and Syrian hamsters, ferrets, and non-human primates. Animal models of SARS-CoV-2 infection have not shown evidence of VAED after immunization, whereas cellular immunopathology has been demonstrated after viral challenge in some animal models administered SARS-CoV-1 or MERS-CoV vaccines (Table 1). Whether or not cellular immunopathology is directly linked to VAED remains unclear as, in many cases, cellular pulmonary infiltrates are not associated with clear respiratory signs or illness. Whereas some in vitro experiments suggest the potential for $\mathrm{ADE}$, their relationship to VAED in animal models has not been established.

SARS-CoV-2 studies in rhesus macaques, African green macaques or cynomolgus macaques (31-36) have demonstrated acute, transient and resolving interstitial pneumonia following virus inoculation, but infection elicits mild-to-moderate pulmonary disease with no progression to respiratory failure or death, unlike COVID-19 in humans with severe illness (32). COVID-19 exhibits greater severity in older humans; two studies in small numbers of aged macaques have suggested greater pulmonary disease due to either SARSCoV-1 (37) or SARS-CoV-2 infection (38) compared to young macaques. Similarly, modified SARS-CoV-1 induces more severe disease in aged versus young mice (39). However, whereas expression of angiotensin converting enzyme 2 (ACE2), the host cell receptor for SARS-CoV-2, has been reported to be higher in the endothelium of aged compared to young cynomolgus macaques (40), humans exhibit an age- 
associated decline in ACE2 expression (41), indicating that factors beyond ACE2 are likely to be critical for disease severity.

In animal models of SARS-CoV-2 infection, rhesus macaques were found to be resistant to SARS-CoV-2 reinfection in two studies, and there was no evidence of enhanced disease from prior infection $(31,32)$. In one study, neutralizing antibody titers correlated with protection from re-infection with SARS-CoV-2 (32). Several COVID-19 vaccines expressing the SARS-CoV-2 spike protein have now been tested in rhesus macaque SARS-CoV-2 challenge models. Vaccines tested include DNA vaccines (35), an inactivated virus vaccine with an alum adjuvant, an adenovirus vector vaccine (33), and a vaccine comprising mRNA encapsulated in lipid nanoparticles (42). Protective efficacy has correlated with the titers of neutralizing antibodies against the spike protein (35), although analyses of $\mathrm{T}$ cell immunity are needed. SARS-CoV-2-infected macaques do develop some lung pathology but they do not show clinical manifestations of COVID-19 or death; VAED or other evidence for immunopathology has not been observed after vaccination followed by SARS-CoV-2 challenge. Observations with SARS-CoV-1 and MERS-CoV vaccines also confirm that high titers of neutralizing antibodies against the spike protein correlate with protection from infection in ferrets and macaques (43-45).

In addition to evidence for protection, cellular infiltrates and immunopathology have been documented in some animal models of SARS-CoV-1 and MERS-CoV infection including mice, hamsters, rats, ferrets, and non-human primates (Table 1). Ferrets immunized with recombinant modified virus vaccinia Ankara (MVA)-expressing SARS-CoV-1 spike protein followed by SARS-CoV-1 virus challenge developed cellular infiltrates in the liver and hepatitis (46). Cellular immunopathology was noted in BALB/c mice immunized with recombinant vaccinia virus expressing the SARS-CoV-2 spike protein or the nucleocapsid antigen, which was linked to increased production of proinflammatory cytokines, especially interleukin (IL)-6 (47). Cellular immunopathology was also observed in BALB/c mice immunized with Venezuelan equine encephalitis virus replicon particles expressing the nucleocapsid protein of SARS-CoV-1 (48).

In a SARS-CoV-1 infection and re-infection model in African green macaques, alveolitis and interstitial pneumonitis associated with dysregulated cellular inflammatory and cytokine responses was observed, but was unrelated to the presence of neutralizing antibodies or evidence of protection (44). Rhesus macaques immunized with MVA vectors encoding the SARS-CoV-1 spike protein also exhibited cellular immunopathology upon virus challenge, which was associated with a combination of IL-8 production and fewer macrophages expressing markers associated with wound healing (45). In both studies, immunopathology occurred despite the presence of high titers of virus neutralizing antibodies $(44,45)$. VAED following SARS-CoV-1 vaccination has been suggested to be associated with vaccine-induced Th17 host responses, including extravasation of eosinophils from the bone marrow and infiltration of tissues $(5,49)$. Thus, the evidence suggests a potential role of Th17 in coronavirus infections that differs from immune enhancement of disease due to the FI-RSV vaccine or dengue virus infection (Fig. 1).

SARS-CoV-1 vaccines comprising inactivated whole virus (with virus inactivation by formalin or UV irradiation), recombinant spike protein (expressed in baculovirus), or chimeric viral-like particles have elicited cellular immunopathology when administered to mice despite the presence of high titers of neutralizing antibodies (50). In these studies, an alum adjuvant was shown to reduce immunopathology compared to non-adjuvanted vaccines, a finding confirmed in mouse immunization experiments with the SARS-CoV-1 spike protein receptor binding domain formulated with alum (51). Other studies have highlighted the importance of inducing Th1 responses as well as CD8+ T cells after vaccination of mice as a means to enhance protective immunity and prevent cellular immunopathology $(45,52-54)$. When MERS-CoV vaccines were tested in non-human primates including a DNA vaccine (55), a MERS-CoV spike protein receptor binding domain subunit vaccine with alum adjuvant, a spike protein subunit vaccine with Ribi adjuvant $(56,57)$, or an adenovirus-vector vaccine expressing MERSCoV spike protein, no lung immunopathology or VAED was observed after challenge with MERS-CoV.

Certain antibodies against the spike protein have been shown to enhance the uptake of SARS-CoV via IgG binding to Fc $\gamma$ RII receptors expressed by cells in vitro $(48,58-60)$. For these studies, fluorescence microscopy and real-time quantitative reverse transcriptase polymerase chain reaction (RTPCR) were used to measure infection of cells in vitro, rather than measuring the capacity of live viruses or pseudoviruses to replicate and produce more viruses in these cells. In vitro studies have shown ADE after infection of cultured cells with MERS-CoV or feline infectious peritonitis virus, an animal coronavirus (61) and (62). For feline infectious peritonitis virus, serum antibodies can coincide with disease onset in cats, but disease may also arise due to mutations in the $3 \mathrm{c}$ gene of non-pathogenic feline enteric coronaviruses leading to increased replication and transmission in the feline gut (61). In the case of MERS-CoV, one in vitro study showed that neutralizing antibodies that bound to the spike protein triggered a conformational change that facilitated virus entry into IgG Fc receptor-expressing cells (62). In a rabbit model of MERS$\mathrm{CoV}, \mathrm{ADE}$ was associated with non-neutralizing antibodies in addition to complement activation and other factors, but did not translate into clinically observable disease $(58-60,62$, 63). An inactivated whole-virus MERS-CoV vaccine elicited 
eosinophilic immunopathology and potentially ADE in mice that was linked to neutralizing antibodies (64). Similarly, in a SARS-CoV-1 challenge model in African green macaques, lung immunopathology was unrelated to pre-existing neutralizing antibodies (44), as was the case for a whole inactivated virus vaccine and other SARS-CoV-1 vaccines in mice (50).

Overall, the immunological mechanisms associated with cellular immunopathology in SARS-CoV and MER-CoV animal models are conflicting, with evidence pointing to both the protective and accelerating properties of Th2 responses and the possibility of pathogenic Th17-derived mechanisms (6). ADE of infection has been seen in vitro for SARS-CoV-1 and MERS-CoV, but it remains unclear whether VAED occurs in animal models administered MERS-CoV or SARS-CoV-1 vaccines.

\section{DOES IMMUNE ENHANCEMENT OF DISEASE OCCUR IN HUMAN CORONAVIRUS INFECTIONS?}

There are seven coronavirus (CoV) serotypes associated with disease in humans: Four that cause the common cold (OC43, NL63, 229E and HKU1) and three that are highly pathogenic (SARS-CoV-1, SARS-CoV-2 and MERS-CoV). Ninety percent of adults are seropositive for coronavirus strains causing the common cold (65). A clinical study where participants were experimentally infected twice, one year apart, with CoV 229E did not report enhanced disease; after the second exposure, the time during which virus was shed in nasal secretions was reduced and there were no symptoms of disease (66). Both serum and nasal IgA antibodies specific for CoV $229 \mathrm{E}$ were associated with a decreased period of nasal virus shedding (67). Immune enhancement of SARS-CoV2 infection attributable to cross-reactive common cold $\mathrm{CoV}$ antibodies has not been reported so far. Rather, prior infection with common cold CoVs has been suggested to be either potentially protective by virtue of inducing antibodies that cross-react with the SARS-CoV-2 spike protein subunit S2 (68) or to be the source of SARS-CoV-2-reactive neutralizing antibodies that arose in a SARS-CoV-1 patient who recovered from SARS-CoV-1 infection (69). Regarding T cell immunity to common cold CoVs, $\sim 40-60 \%$ of individuals who have not been exposed to SARS-CoV-2 have SARS-CoV-2 reactive CD4+ $\mathrm{T}$ cells, suggesting that there is cross-reactive $\mathrm{T}$ cell recognition between common cold CoVs and SARS-CoV-2 (70, 71). So far, there is no direct evidence suggesting that pre-existing immunity to common cold CoVs is detrimental to the outcome of SARS-CoV-2 infection.

Reports correlating antibody responses and disease severity are conflicting and confounded by higher viral loads and the potential for more immune stimulation with severe SARS-CoV-2 infection. Studies of MERS-CoV have shown increased neutralizing antibodies (72-74) or an increased duration of spike protein-binding antibody (75) in severe disease. Among 128 SARS-CoV-1-infected individuals the amount of neutralizing antibodies was not associated with disease severity (76). However, one report suggested that increased antibody production correlated with increased respiratory failure in humans infected with SARS-CoV-1 (77). In contrast, another study showed no difference in time to seroconversion in SARS-CoV-1-infected individuals who survived compared to those who died (78). The presence of SARS-CoV1-specific IgG 10 days after onset of symptoms was associated with a decrease in nasopharyngeal viral load and with worsening of clinical disease in $\sim 20 \%$ of individuals with respiratory failure requiring ventilator support (79). Use of a pseudovirus and a plaque reduction neutralization test (PRNT) assay to study acutely ill and recovered SARS-CoV-1infected patients showed a decrease in viral load coincident with the time of seroconversion, suggesting that the neutralizing antibody response may play a role in clearance of virus $(80,81)$. In the setting of SARS-CoV-1 infection, it has been reported that $\mathrm{CD} 4+\mathrm{T}$ cell responses correlated with positive outcomes in mice (82), but more severe disease in humans (76).

Tam et al. have suggested that IgM and IgG against the SARS-CoV-2 nucleocapsid protein increased in patients with severe compared to mild COVID-19 disease (83). Systems analysis of serological signatures in COVID-19 disease revealed functional antibody responses to SARS-CoV-2 nucleocapsid protein were elevated in those who died, whereas spike-specific antibody responses were enriched among convalescent individuals (84). A clinical study of 175 patients with COVID-19 reported that higher serum neutralizing antibody titers may be associated with lower lymphocyte counts and higher C-reactive protein (85), but the amount of neutralizing antibodies in severe compared to mild disease was not reported. Studies have reported higher SARS-CoV-2 neutralizing antibody titers in old compared to young patients with COVID-19 $(85,86)$. One study reported higher IgM and IgG antibodies against SARS-CoV-2 spike and nucleocapsid proteins in patients with severe compared to mild COVID-19 disease (87). A second study of mild versus severe COVID-19 disease in SARS-CoV-2-infected individuals demonstrated elevated serum IgA and IgG antibodies against virus spike protein associated with severe disease. In individuals who had recovered from SARS-CoV-2 infection, spike protein-specific CD4+ T cell responses correlated with the magnitude of IgG and IgA antibody titers against the spike protein receptor binding domain (71). The reason for higher anti-spike protein antibody responses in severe COVID-19 disease is not clear, but may be due to higher viral loads in severe disease (88). Indeed, studies have demonstrated that the nasopharyngeal SARS-CoV-2 viral load was higher in elderly patients and in severe disease compared to mild disease $(89,90)$. However, 
in other studies, no association was found between nasopharyngeal viral load and disease severity (91).

Two studies involving re-infection of non human primates with SARS-CoV-2 after a primary infection showed that the animals were resistant to re-infection with no evidence of enhanced disease $(31,32)$. Recently, one patient in the United States was reported to have a more severe clinical course when infected with SARS-CoV-2 a second time (92). While it is difficult to interpret data from a single case report, it will be important to monitor the frequency of repeat infections with SARS-CoV-2 and the clinical course of disease to determine if this finding is relevant more broadly.

Lung pathology in COVID-19 disease is characterized by diffuse alveolar damage, with hyaline membrane formation, pneumocyte desquamation, multi-nucleated giant cell formation, neutrophil or macrophage alveolar infiltrates and viral infection of several cell types $(7,93,94)$. Viral proteins can be detected in upper airway and bronchiolar epithelium, submucosal gland epithelium and in type I and type II lung pneumocytes, alveolar macrophages and the hyaline membranes of the lung (94).

In COVID-19, disease severity and death have been associated with higher amounts of inflammatory markers in the blood and increased concentrations of serum inflammatory cytokines and chemokines (95). Predictors of severe COVID19 disease are emerging, with lymphopenia, elevated serum C-reactive protein, ferritin, and D-dimers, and high serum concentrations of IL-6, IL-10, IP-10/CXCL10 and TNF- $\alpha$ (96, 97 ) in some patients $(95,97)$. Dysregulated cytokine induction has also been reported in acute respiratory distress syndrome in patients infected with SARS-CoV-1 or MERS-CoV (98-101). Recently, the similarity between acute respiratory distress syndrome associated with severe $\mathrm{CoV}$ respiratory infections and acute respiratory distress syndrome that occurs during immunotherapy with chimeric antigen receptor (CAR) $\mathrm{T}$ cells has been pointed out (102).

\section{WHAT VACCINE TRIALS AND CONVALESCENT PLASIMA REVEAL ABOUT IMIMUNE ENHANCEMENT OF DISEASE}

In phase 1 clinical trials, a MERS-CoV DNA vaccine was well tolerated (NCT03721718) (103) as was an MVA vectorspike protein vaccine (NCT03615911) (104). A chimp adenovirus vector (ChAdOx1) vaccine expressing the MERS-CoV spike protein did not result in any severe adverse events over a 12-month follow-up period in 24 trial participants, and all mild or moderate adverse events resolved within 6 days (NCT03399578) (105). Moreover, no evidence of immune enhancement of disease was noted in a clinical trial of an inactivated whole virus SARS-CoV-1 vaccine (106) or a DNA vaccine expressing SARS-CoV-1 spike protein in 10 individuals (NCT00099463) (107). Infection was not reported after vaccination in any of these trials.

To date, five different phase 1 studies of vaccines against SARS-CoV-2 have been published (NCT04368728, NCT04313127, NCT04324606, NCT04283461) (108). Mild to moderate adverse events were commonly reported with low rates of severe adverse events (108-111). However, these early phase 1 trials are not sufficiently powered to be able to definitively demonstrate that serious adverse events including VAED are not associated with COVID-19 vaccines. Phase 3 efficacy trials for COVID-19 candidate vaccines have begun in regions of ongoing SARS-CoV-2 transmission, including the US, UK, South Africa, and Latin America. These phase 3 trials will follow participants for at least one year to monitor efficacy outcomes and safety in the context of ongoing SARS$\mathrm{CoV}-2$ infection, and will provide direct data for these vaccine candidates regarding disease enhancement following vaccination. Importantly, in phase 2 and 3 trials using the chimp adenovirus vector vaccine (ChimpAdOx-1), there have been early reports of two possible cases of inflammatory neurological disease (transverse myelitis) in trial participants, and this phase 3 trial has been paused in the US at this time $(112,113)$.

Another approach for elucidating potential complications caused by neutralizing antibodies or other antibodies to SARS-CoV-2 during ongoing infection is to determine whether administration of convalescent plasma from COVID19 patients enhances disease in recipients. Uncontrolled studies of convalescent plasma administration to more than 35,000 severely ill patients with COVID-19 have shown that antibody administration in the form of plasma transfusions is not associated with worsening of disease (114). A matchedcontrol trial of convalescent serum administration to 45 patients with COVID-19 demonstrated a decrease in oxygen supplement requirements and an overall survival benefit in the treated group compared to the untreated group (115). Randomized controlled trials of convalescent serum treatment are underway (NCT04348656, NCT04342182, NCT04338360). To date, there is no consistent evidence of immune enhancement of SARS-CoV-2 infection in humans from data from natural infection, various vaccine candidates or convalescent plasma treatment.

\section{IMPLICATIONS OF IMIMUNE ENHANCEMENT OF DISEASE FOR VACCINE DEVELOPMENT}

A key question is why VAED is raised as a possibility for COVID-19 vaccines. Fundamentally, this question should be asked of all vaccine candidates under development, despite the rarity of the phenomenon. If judged safe and effective by regulatory authorities based on efficacy clinical trials that could include up to 30,000 participants per trial, COVID-19 vaccines could be made rapidly available to far larger numbers of people. Although determinations of vaccine safety and efficacy will be based on well-established requirements of 
regulatory authorities in the United States, the European Union and other global regions, the capacity to produce and deliver millions of vaccine doses has been accelerated in order to gain control of the pandemic. As a result, many people may be vaccinated before longer-term follow-up is possible. In addition, COVID-19 vaccines will be administered to older individuals who are naïve to this pathogen, whereas knowledge about vaccine responses in this age group has often come from vaccines designed to boost waning immunity. However, age-related differences in immune responses are being evaluated in phase 3 COVID-19 vaccine trials.

Given current knowledge, the main opportunity to identify whether a COVID-19 vaccine candidate has a risk of VAED will be in randomized, placebo-controlled phase 3 clinical trials. Whether and when such a risk would be identified in clinical trials depends on three important factors: (1) the frequency of VAED, (2) the time interval after vaccination when VAED might occur, and (3) whether the manifestation of VAED is distinct from natural disease of a similar severity. Currently, it is unknown if there would be clinical markers to distinguish VAED from natural COVID-19 disease. The inherent complexity of COVID-19 including non-respiratory manifestations such as coagulopathy in adults (116) and multisystem inflammatory syndrome in children, may make this distinction particularly difficult. Nonetheless, the occurrence of severe disease with a higher than expected frequency in a particular age group may be important as a potential signal of VAED.

The design of COVID-19 vaccine clinical trials takes these points into account by progressing from small (approximately 100 person) phase 1 safety trials through large ( 30,000 person) phase 3 efficacy trials (117). The primary efficacy analysis in a phase 3 trial may occur less than 12 months after the start of the phase 1 trial, and phase 3 trials are expected to include enough incident COVID-19 cases (e.g., 150 infection events) at that point to confidently assess whether a vaccine candidate is reducing disease incidence by a factor of 2 or greater (118). All phase 3 trial participants are expected to be followed for at least one year (118). Thus, it is critical to implement and complete phase 3 efficacy studies to ensure that the vaccine is both safe and efficacious. Given the duration of the clinical trials, VAED will be identified if there is little delay after vaccination before the putative risk of VAED develops. If VAED occurred during a trial and was not distinguishable from natural disease, clinical trials might identify it through an increase in the rate of morbidity or mortality in the vaccinated group compared to the control group (Table 2). Alternatively, if VAED occurred and was distinguishable from natural disease, then clinical trials might be able to identify much lower rates of VAED. FDA guidelines for industry for emergency use authorization for vaccines to prevent COVID-19 were recently issued. These guidelines require that the trials (1) meet the prespecified success criteria for the study's primary efficacy endpoint, (2) provide all safety data from Phase 1, 2 and 3 trials, (3) conduct follow-up of phase 3 participants for a median duration of at least 2 months after completion of the full vaccination regimen, and (4) report 5 or more severe COVID-19 cases in the placebo group to assess the possibility of VAED in the vaccine group (119).

Participants in phase 3 vaccine trials are monitored to detect adverse events ranging from mild to severe. A severe adverse event triggers a pause in the trial while a comprehensive assessment of causality for relatedness to vaccine administration is completed by an independent review committee, as occurred in the chimp adenovirus vector vaccine study $(120,121)$.

If data from phase 3 efficacy trials demonstrate that vaccine candidates meet the safety, efficacy, and quality standards set by regulators, then vaccine candidates may be licensed for use. The possibility of adverse events too rare for identification in clinical trials is assumed for all licensed vaccines. There remains the theoretical possibility that COVID19 vaccine recipients might develop VAED after infection with SARS-CoV-2 at a frequency too low to be detected during the clinical trials or occurring after the clinical trials have ended. This possibility will need to be addressed by post-licensure surveillance. The appropriate methods for post-licensure surveillance will depend on whether the manifestations of VAED are distinct from those of COVID-19 disease, which would allow the development of a case definition of VAED. Established methods for post-licensure vaccine effectiveness studies, such as a case-control design, can monitor for increased rates of severe disease following vaccination. Regulators may recommend specific types of studies to assess the potential for VAED related to COVID-19 vaccines (118), and sponsors of licensed vaccines may be required by regulatory authorities to monitor for known and unidentified risks after licensure. Implementing post-vaccination surveillance procedures in the US is the responsibility of the FDA and the CDC (122).

Finally, because of the unprecedented number of COVID19 vaccines in development, there will be a very large body of clinical data available for different vaccines and the placebo groups. This will provide the opportunity for meta-analyses across many studies to better understand the immunopathology of COVID-19 disease in different age groups and to look for severe adverse events such as VAED that may be rare.

Clinical trials of other prophylactic interventions, such as convalescent plasma, hyperimmune globulin, and monoclonal antibodies, will evaluate protective efficacy and potential immune-associated enhanced disease as described for vaccine clinical trials. To the extent that vaccines elicit similar antibody responses, these data will provide evidence about 
mechanisms of protection and, if present, VAED, with the caveat that vaccine-induced immune responses are expected to have notable differences from antibody-based interventions given that vaccines will likely induce both antibodies and $\mathrm{T}$ cell responses.

Animal models of SARS-CoV-2 infection will continue to evolve as researchers attempt to identify models in young and aged animals that recapitulate more severe human COVID-19 disease presentation. However, unless immune enhanced disease is observed in humans, there will not be a way to evaluate whether any animal models are predictive of VAED in vaccinated humans. Although human challenge studies cannot be performed with SARS-CoV-2 in the absence of effective antiviral agents, infection of volunteers using minimally pathogenic coronaviruses may provide insights about immune correlates of protection against these viruses (123).

\section{CONCLUSIONS}

We conclude that the available data do not support more concern about VAED for COVID-19 vaccines than is appropriate for the development of any viral vaccine. Convalescent plasma studies suggest potential benefit rather than a risk of more severe disease. In addition, no serious safety signals have been reported from initial phase 1 trials of COVID-19 vaccine candidates, with the caveat that the number of vaccinees who have been subsequently exposed to SARS-CoV-2 infection is unknown but probably low. Nevertheless, an abundance of caution to exclude such a concern is warranted in order to be able to implement efficacious COVID-19 vaccines as widely, rapidly and safely as possible.

Our analysis also finds that in non-clinical reports where immune-associated enhanced disease, cellular immunopathology, and $\mathrm{ADE}$ of disease have been observed, no consistent mechanism or immune markers of disease enhancement are apparent. Also, importantly, there is no evidence that any of the in vitro or animal models of coronavirus infection reliably predict the human experience. Thus, it is not possible to clearly prioritize or down-select vaccine antigens, adjuvants, biotechnology platforms, or delivery mechanisms based on general immunological principles or the available preclinical data. Ultimately, the only way to address the theoretical risk of VAED is in phase 3 efficacy trials with sufficient numbers of endpoints to evaluate safety and efficacy, and by post-licensure surveillance. If VAED is frequent or clinically distinctive, it should become apparent when clinical trial participants experience natural infection with SARS-CoV-2. The combination of protection against COVID-19 and the lack of VAED in clinical trials would provide important assurances of the efficacy and safety of the vaccine and the justification for vaccine use. However, the detection of low rates of VAED, associated with a later exposure to SARS-CoV-2 in people who have been vaccinated, will depend on rigorous post-licensure surveillance, as is necessary when any new viral vaccine is introduced for the prevention of morbidity and mortality that would otherwise be caused by a human viral pathogen. Thus, completion and full evaluation of COVID-19 vaccine phase 3 efficacy trials with long-term follow-up and post-licensure surveillance will provide the most comprehensive data on the safety of COVID-19 vaccines and the potential risk of VAED.

\section{REFERENCES AND NOTES}

1. B. S. Graham, Rapid COVID-19 vaccine development. Science 368, 945-946 (2020). doi:10.1126/science.abb8923 Medline

2. Draft landscape of COVID-19 candidate vaccines (https://www.who.int/publications/m/item/draft-landscape-of-covid-19candidate-vaccines)

3. M. Chan, "Ten years in public health 2007-2017," (World Health Organization, 2017).

4. L. A. Lee, L. Franzel, J. Atwell, S. D. Datta, I. K. Friberg, S. J. Goldie, S. E. Reef, N. Schwalbe, E. Simons, P. M. Strebel, S. Sweet, C. Suraratdecha, Y. Tam, E. Vynnycky, N. Walker, D. G. Walker, P. M. Hansen, The estimated mortality impact of vaccinations forecast to be administered during 2011-2020 in 73 countries supported by the GAVI Alliance. Vaccine 31 (Suppl 2), B61-B72 (2013). doi:10.1016/i.vaccine.2012.11.035 Medline

5. P. J. Hotez, D. B. Corry, M. E. Bottazzi, COVID-19 vaccine design: The Janus face of immune enhancement. Nat. Rev. Immunol. 20, 347-348 (2020). doi:10.1038/s41577-020-0323-4 Medline

6. A. Iwasaki, Y. Yang, The potential danger of suboptimal antibody responses in COVID-19. Nat. Rev. Immunol. 20, 339-341 (2020). doi:10.1038/s41577-0200321-6 Medline

7. A. M. Arvin, K. Fink, M. A. Schmid, A. Cathcart, R. Spreafico, C. Havenar-Daughton, A. Lanzavecchia, D. Corti, H. W. Virgin, A perspective on potential antibodydependent enhancement of SARS-CoV-2. Nature 584, 353-363 (2020). doi:10.1038/s41586-020-2538-8 Medline

8. S. Bournazos, A. Gupta, J. V. Ravetch, The role of IgG Fc receptors in antibodydependent enhancement. Nat. Rev. Immunol. 20, 633-643 (2020). Medline

9. P. H. Lambert, D. M. Ambrosino, S. R. Andersen, R. S. Baric, S. B. Black, R. T. Chen, C. L. Dekker, A. M. Didierlaurent, B. S. Graham, S. D. Martin, D. C. Molrine, S. Perlman, P. A. Picard-Fraser, A. J. Pollard, C. Qin, K. Subbarao, J. P. Cramer, Consensus summary report for CEPI/BC March 12-13, 2020 meeting: Assessment of risk of disease enhancement with COVID-19 vaccines. Vaccine 38 4783-4791 (2020). doi:10.1016/ivaccine.2020.05.064 Medline

10. J. Chin, R. L. Magoffin, L. A. Shearer, J. H. Schieble, E. H. Lennette, Field evaluation of a respiratory syncytial virus vaccine and a trivalent parainfluenza virus vaccine in a pediatric population. Am. J. Epidemiol. 89, 449-463 (1969). doi:10.1093/oxfordjournals.aje.a120957 Medline

11. V. A. Fulginiti, J. J. Eller, O. F. Sieber, J. W. Joyner, M. Minamitani, G. Meiklejohn, Respiratory virus immunization. I. A field trial of two inactivated respiratory virus vaccines; an aqueous trivalent parainfluenza virus vaccine and an alumprecipitated respiratory syncytial virus vaccine. Am. J. Epidemiol. 89, 435-448 (1969). doi:10.1093/oxfordjournals.aje.a120956 Medline

12. H. W. Kim, J. G. Canchola, C. D. Brandt, G. Pyles, R. M. Chanock, K. Jensen, R. H. Parrott, Respiratory syncytial virus disease in infants despite prior administration of antigenic inactivated vaccine. Am. J. Epidemiol. 89, 422-434 (1969). doi:10.1093/oxfordjournals.aje.a120955 Medline

13. A. M. Killikelly, M. Kanekiyo, B. S. Graham, Pre-fusion F is absent on the surface of formalin-inactivated respiratory syncytial virus. Sci. Rep. 6, 34108 (2016). doi:10.1038/srep34108 Medline

14. B. R. Murphy, G. A. Prince, E. E. Walsh, H. W. Kim, R. H. Parrott, V. G. Hemming, W. J. Rodriguez, R. M. Chanock, Dissociation between serum neutralizing and glycoprotein antibody responses of infants and children who received inactivated respiratory syncytial virus vaccine. J. Clin. Microbiol. 24, 197-202 (1986). doi:10.1128/JCM.24.2.197-202.1986 Medline 
15. G. A. Prince, A. B. Jenson, V. G. Hemming, B. R. Murphy, E. E. Walsh, R. L. Horswood, R. M. Chanock, Enhancement of respiratory syncytial virus pulmonary pathology in cotton rats by prior intramuscular inoculation of formalin-inactiva ted virus. J. Virol. 57, 721-728 (1986). doi:10.1128/JVI.57.3.721-728.1986 Medline

16. G. A. Prince, S. J. Curtis, K. C. Yim, D. D. Porter, Vaccine-enhanced respiratory syncytial virus disease in cotton rats following immunization with Lot 100 or a newly prepared reference vaccine. J. Gen. Virol. 82, 2881-2888 (2001). doi:10.1099/0022-1317-82-12-2881 Medline

17. F. P. Polack, M. N. Teng, P. L. Collins, G. A. Prince, M. Exner, H. Regele, D. D. Lirman, R. Rabold, S. J. Hoffman, C. L. Karp, S. R. Kleeberger, M. Wills-Karp, R. A. Karron, A role for immune complexes in enhanced respiratory syncytial virus disease. $J$. Exp. Med. 196, 859-865 (2002). doi:10.1084/jem.20020781 Medline

18. M. F. Delgado, S. Coviello, A. C. Monsalvo, G. A. Melendi, J. Z. Hernandez, J. P. Batalle, L. Diaz, A. Trento, H.-Y. Chang, W. Mitzner, J. Ravetch, J. A. Melero, P. M. Irusta, F. P. Polack, Lack of antibody affinity maturation due to poor Toll-like receptor stimulation leads to enhanced respiratory syncytial virus disease. Nat. Med. 15, 34-41 (2009). doi:10.1038/nm.1894 Medline

19. S. K. Browne, J. A. Beeler, J. N. Roberts, Summary of the Vaccines and Related Biological Products Advisory Committee meeting held to consider evaluation of vaccine candidates for the prevention of respiratory syncytial virus disease in RSV-naïve infants. Vaccine 38, 101-106 (2020). doi:10.1016/j.vaccine.2019.10.048 Medline

20. L. W. Rauh, R. Schmidt, Measles immunization with killed virus vaccine: Serum antibody titers and experience with exposure to measles epidemic. Am. J. Dis. Child. 109, 232-237 (1965). doi:10.1001/archpedi.1965.02090020234007 Medline

21. J. C. Bester, Measles and Measles Vaccination: A Review. JAMA Pediatr. 170, 1209-1215 (2016). doi:10.1001/jamapediatrics.2016.1787 Medline

22. C. P. Simmons, J. J. Farrar, V. Nguyen, B. Wills, Dengue. N. Engl. J. Med. 366, 14231432 (2012). doi:10.1056/NEJMra1110265 Medline

23. L. C. Katzelnick, L. Gresh, M. E. Halloran, J. C. Mercado, G. Kuan, A. Gordon, A Balmaseda, E. Harris, Antibody-dependent enhancement of severe dengue disease in humans. Science 358, 929-932 (2017). doi:10.1126/science.aan6836 Medline

24. S. J. Thomas, I. K. Yoon, A review of Dengvaxia ${ }^{\circledR}$ Development to deployment. Hum. Vaccin. Immunother. 15, 2295-2314 (2019). doi:10.1080/21645515.2019.1658503 Medline

25. Dengue vaccine: WHO position paper, September 2018 - Recommendations. Vaccine 37, 4848-4849 (2019). doi:10.1016/j.vaccine.2018.09.063 Medline

26. A. C. Monsalvo, J. P. Batalle, M. F. Lopez, J. C. Krause, J. Klemenc, J. Z. Hernandez, B. Maskin, J. Bugna, C. Rubinstein, L. Aguilar, L. Dalurzo, R. Libster, V. Savy, E. Baumeister, L. Aguilar, G. Cabral, J. Font, L. Solari, K. P. Weller, J. Johnson, M. Echavarria, K. M. Edwards, J. D. Chappell, J. E. Crowe Jr., J. V. Williams, G. A. Melendi, F. P. Polack, Severe pandemic 2009 H1N1 influenza disease due to pathogenic immune complexes. Nat. Med. 17, 195-199 (2011). doi:10.1038/nm.2262 Medline

27. M. T. Osterholm, N. S. Kelley, A. Sommer, E. A. Belongia, Efficacy and effectiveness of influenza vaccines: A systematic review and meta-analysis. Lancet Infect. Dis. 12, 36-44 (2012). doi:10.1016/S1473-3099(11)70295-X Medline

28. D. M. Skowronski, G. De Serres, N. S. Crowcroft, N. Z. Janjua, N. Boulianne, T. S. Hottes, L. C. Rosella, J. A. Dickinson, R. Gilca, P. Sethi, N. Ouhoummane, D. J. Willison, I. Rouleau, M. Petric, K. Fonseca, S. J. Drews, A. Rebbapragada, H. Charest, M.'È. Hamelin, G. Boivin, J. L. Gardy, Y. Li, T. L. Kwindt, D. M. Patrick, R. C. Brunham; Canadian SAVOIR Team, Association between the 2008-09 seasonal influenza vaccine and pandemic H1N1 illness during Spring-Summer 2009: Four observational studies from Canada. PLOS Med. 7, e1000258 (2010). doi:10.1371/journal.pmed.1000258 Medline

29. L. E. Lansbury, S. Smith, W. Beyer, E. Karamehic, E. Pasic-Juhas, H. Sikira, A. Mateus, H. Oshitani, H. Zhao, C. R. Beck, J. S. Nguyen-Van-Tam, Effectiveness of 2009 pandemic influenza A(H1N1) vaccines: A systematic review and metaanalysis. Vaccine 35, 1996-2006 (2017). doi:10.1016/i.vaccine.2017.02.059 Medline

30. Centers for Disease Control and Prevention (CDC), Effectiveness of 2008-09 trivalent influenza vaccine against 2009 pandemic influenza A (H1N1) - United States, May-June 2009. Morbidity and mortality weekly report 58, 1241-1245
(2009). Medline

31. L. Bao et al., Reinfection could not occur in SARS-CoV-2 infected rhesus macaques. 2020 (10.1101/2020.03.13.990226\% J bioRxiv).

32. A. Chandrashekar, J. Liu, A. J. Martinot, K. McMahan, N. B. Mercado, L. Peter, L. H. Tostanoski, J. Yu, Z. Maliga, M. Nekorchuk, K. Busman-Sahay, M. Terry, L. M. Wrijil, S. Ducat, D. R. Martinez, C. Atyeo, S. Fischinger, J. S. Burke, M. D. Slein, L. Pessaint, A. Van Ry, J. Greenhouse, T. Taylor, K. Blade, A. Cook, B. Finneyfrock, R. Brown, E. Teow, J. Velasco, R. Zahn, F. Wegmann, P. Abbink, E. A. Bondzie, G. Dagotto, M. S. Gebre, X. He, C. Jacob-Dolan, N. Kordana, Z. Li, M. A. Lifton, S. H. Mahrokhian, L. F. Maxfield, R. Nityanandam, J. P. Nkolola, A. G. Schmidt, A. D. Miller, R. S. Baric, G. Alter, P. K. Sorger, J. D. Estes, H. Andersen, M. G. Lewis, D. H. Barouch, SARS-CoV-2 infection protects against rechallenge in rhesus macaques. Science 369, 812-817 (2020). doi:10.1126/science.abc4776 Medline

33. Y. Chen et al., Protection of Rhesus Macaque from SARS-Coronavirus challenge by recombinant adenovirus vaccine. 2020 (10.1101/2020.02.17.951939\% J bioRxiv).

34. Q. Gao, L. Bao, H. Mao, L. Wang, K. Xu, M. Yang, Y. Li, L. Zhu, N. Wang, Z. Lv, H. Gao, X. Ge, B. Kan, Y. Hu, J. Liu, F. Cai, D. Jiang, Y. Yin, C. Qin, J. Li, X. Gong, X. Lou, W. Shi, D. Wu, H. Zhang, L. Zhu, W. Deng, Y. Li, J. Lu, C. Li, X. Wang, W. Yin, Y. Zhang, C. Qin, Development of an inactivated vaccine candidate for SARS-CoV-2. Science 369, 77-81 (2020). doi:10.1126/science.abc1932 Medline

35. J. Yu, L. H. Tostanoski, L. Peter, N. B. Mercado, K. McMahan, S. H. Mahrokhian, J. P. Nkolola, J. Liu, Z. Li, A. Chandrashekar, D. R. Martinez, C. Loos, C. Atyeo, S. Fischinger, J. S. Burke, M. D. Slein, Y. Chen, A. Zuiani, F. J. N. Lelis, M. Travers, S. Habibi, L. Pessaint, A. Van Ry, K. Blade, R. Brown, A. Cook, B. Finneyfrock, A. Dodson, E. Teow, J. Velasco, R. Zahn, F. Wegmann, E. A. Bondzie, G. Dagotto, M. S. Gebre, X. He, C. Jacob-Dolan, M. Kirilova, N. Kordana, Z. Lin, L. F. Maxfield, F. Nampanya, R. Nityanandam, J. D. Ventura, H. Wan, Y. Cai, B. Chen, A. G. Schmidt, D. R. Wesemann, R. S. Baric, G. Alter, H. Andersen, M. G. Lewis, D. H. Barouch, DNA vaccine protection against SARS-CoV-2 in rhesus macaques. Science 369 , 806-811 (2020). doi:10.1126/science.abc6284 Medline

36. R. W. Cross, K. N. Agans, A. N. Prasad, V. Borisevich, C. Woolsey, D. J. Deer, N. S. Dobias, J. B. Geisbert, K. A. Fenton, T. W. Geisbert, Intranasal exposure of African green monkeys to SARS-CoV-2 results in acute phase pneumonia with shedding and lung injury still present in the early convalescence phase. Virol. J. 17, 125 (2020). doi:10.1186/s12985-020-01396-w Medline

37. S. L. Smits, A. de Lang, J. M. A. van den Brand, L. M. Leijten, W. F. van IJcken, M. J. C. Eijkemans, G. van Amerongen, T. Kuiken, A. C. Andeweg, A. D. M. E. Osterhaus, B. L. Haagmans, Exacerbated innate host response to SARS-CoV in aged nonhuman primates. PLOS Pathog. 6, e1000756 (2010). doi:10.1371/journal.ppat.1000756 Medline

38. P. Yu, F. Qi, Y. Xu, F. Li, P. Liu, J. Liu, L. Bao, W. Deng, H. Gao, Z. Xiang, C. Xiao, Q. Lv, S. Gong, J. Liu, Z. Song, Y. Qu, J. Xue, Q. Wei, M. Liu, G. Wang, S. Wang, H. Yu, X. Liu, B. Huang, W. Wang, L. Zhao, H. Wang, F. Ye, W. Zhou, W. Zhen, J. Han, G. Wu, Q. Jin, J. Wang, W. Tan, C. Qin, Age-related rhesus macaque models of COVID19. Animal Model Exp Med 3, 93-97 (2020). doi:10.1002/ame2.12108 Medline

39. M. Frieman, B. Yount, S. Agnihothram, C. Page, E. Donaldson, A. Roberts, L. Vogel, B. Woodruff, D. Scorpio, K. Subbarao, R. S. Baric, Molecular determinants of severe acute respiratory syndrome coronavirus pathogenesis and virulence in young and aged mouse models of human disease. J. Virol. 86, 884-897 (2012). doi:10.1128/JVI.05957-11 Medline

40. M. Wang et al., Aging increases aortic MMP-2 activity and angiotensin II in nonhuman primates. Hypertension 41, 1308-1316 (2003).

41. M. AIGhatrif, O. Cingolani, E. G. Lakatta, The Dilemma of Coronavirus Disease 2019, Aging, and Cardiovascular Disease: Insights From Cardiovascular Aging Science. JAMA Cardiol. 5, 747-748 (2020). doi:10.1001/jamacardio.2020.1329 Medline

42. K. S. Corbett, B. Flynn, K. E. Foulds, J. R. Francica, S. Boyoglu-Barnum, A. P. Werner, B. Flach, S. O'Connell, K. W. Bock, M. Minai, B. M. Nagata, H. Andersen, D. R. Martinez, A. T. Noe, N. Douek, M. M. Donaldson, N. N. Nji, G. S. Alvarado, D. K. Edwards, D. R. Flebbe, E. Lamb, N. A. Doria-Rose, B. C. Lin, M. K. Louder, S. O'Dell, S. D. Schmidt, E. Phung, L. A. Chang, C. Yap, J. M. Todd, L. Pessaint, A. Van Ry, S. Browne, J. Greenhouse, T. Putman-Taylor, A. Strasbaugh, T.-A. Campbell, A. Cook, A. Dodson, K. Steingrebe, W. Shi, Y. Zhang, O. M. Abiona, L. Wang, A. Pegu, E. S. Yang, K. Leung, T. Zhou, I.-T. Teng, A. Widge, I. Gordon, L. Novik, R. A. Gillespie, R. J. Loomis, J. I. Moliva, G. Stewart-Jones, S. Himansu, W.-P. Kong, M. 
C. Nason, K. M. Morabito, T. J. Ruckwardt, J. E. Ledgerwood, M. R. Gaudinski, P. D. Kwong, J. R. Mascola, A. Carfi, M. G. Lewis, R. S. Baric, A. McDermott, I. N. Moore, N. J. Sullivan, M. Roederer, R. A. Seder, B. S. Graham, Evaluation of the mRNA1273 Vaccine against SARS-CoV-2 in Nonhuman Primates. N. Engl. J. Med. 383, 1544-1555 (2020). doi:10.1056/NEJMoa2024671 Medline

43. Y. K. Chu, G. D. Ali, F. Jia, Q. Li, D. Kelvin, R. C. Couch, K. S. Harrod, J. A. Hutt, C. Cameron, S. R. Weiss, C. B. Jonsson, The SARS-CoV ferret model in an infectionchallenge study. Virology 374, 151-163 (2008). doi:10.1016/j.virol.2007.12.032 Medline

44. C. Clay, N. Donart, N. Fomukong, J. B. Knight, W. Lei, L. Price, F. Hahn, J. Van Westrienen, K. S. Harrod, Primary severe acute respiratory syndrome coronavirus infection limits replication but not lung inflammation upon homologous rechallenge. J. Virol. 86, 4234-4244 (2012). doi:10.1128/JVI.06791-11 Medline

45. L. Liu, Q. Wei, Q. Lin, J. Fang, H. Wang, H. Kwok, H. Tang, K. Nishiura, J. Peng, Z. Tan, T. Wu, K.-W. Cheung, K.-H. Chan, X. Alvarez, C. Qin, A. Lackner, S. Perlman, K.-Y. Yuen, Z. Chen, Anti-spike IgG causes severe acute lung injury by skewing macrophage responses during acute SARS-CoV infection. JCI Insight 4, e123158 (2019). doi:10.1172/ici.insight.123158 Medline

46. M. Czub, H. Weingartl, S. Czub, R. He, J. Cao, Evaluation of modified vaccinia virus Ankara based recombinant SARS vaccine in ferrets. Vaccine 23, 2273-2279 (2005). doi:10.1016/i.vaccine.2005.01.033 Medline

47. F. Yasui, C. Kai, M. Kitabatake, S. Inoue, M. Yoneda, S. Yokochi, R. Kase, S. Sekiguchi, K. Morita, T. Hishima, H. Suzuki, K. Karamatsu, Y. Yasutomi, H. Shida, M. Kidokoro, K. Mizuno, K. Matsushima, M. Kohara, Prior immunization with severe acute respiratory syndrome (SARS)-associated coronavirus (SARS-CoV) nucleocapsid protein causes severe pneumonia in mice infected with SARS-CoV. J. Immunol. 181, 6337-6348 (2008). doi:10.4049/iimmunol.181.9.6337 Medline

48. D. Deming, T. Sheahan, M. Heise, B. Yount, N. Davis, A. Sims, M. Suthar, J. Harkema, A. Whitmore, R. Pickles, A. West, E. Donaldson, K. Curtis, R. Johnston, R. Baric, Vaccine efficacy in senescent mice challenged with recombinant SARSCoV bearing epidemic and zoonotic spike variants. PLOS Med. 3, e525 (2006). doi:10.1371/journal.pmed.0030525 Medline

49. P. J. Hotez, M. E. Bottazzi, D. B. Corry, The potential role of Th17 immune responses in coronavirus immunopathology and vaccine-induced immune enhancement. Microbes Infect. 22, 165-167 (2020). doi:10.1016/i.micinf.2020.04.005 Medline

50. C. T. Tseng, E. Sbrana, N. Iwata-Yoshikawa, P. C. Newman, T. Garron, R. L. Atmar, C. J. Peters, R. B. Couch, Immunization with SARS coronavirus vaccines leads to pulmonary immunopathology on challenge with the SARS virus. PLOS ONE 7, e35421 (2012). doi:10.1371/journal.pone.0035421 Medline

51. W.-H. Chen et al., Yeast-Expressed SARS-CoV Recombinant Receptor-Binding Domain (RBD219-N1) Formulated with Alum Induces Protective Immunity and Reduces Immune Enhancement. 2020 (10.1101/2020.05.15.098079\% J bioRxiv).

52. R. Channappanavar, C. Fett, J. Zhao, D. K. Meyerholz, S. Perlman, Virus-specific memory CD8 T cells provide substantial protection from lethal severe acute respiratory syndrome coronavirus infection. J. Virol. 88, 11034-11044 (2014). doi:10.1128/JVL.01505-14 Medline

53. Y. Honda-Okubo, D. Barnard, C. H. Ong, B.-H. Peng, C.-T. K. Tseng, N. Petrovsky, Severe acute respiratory syndrome-associated coronavirus vaccines formulated with delta inulin adjuvants provide enhanced protection while ameliorating lung eosinophilic immunopathology. J. Virol. 89, 2995-3007 (2015). doi:10.1128/JVI.02980-14 Medline

54. J. Zhao, J. Zhao, S. Perlman, T cell responses are required for protection from clinical disease and for virus clearance in severe acute respiratory syndrome coronavirus-infected mice. J. Virol. 84, 9318-9325 (2010). doi:10.1128/JVl.01049-10 Medline

55. K. Muthumani, D. Falzarano, E. L. Reuschel, C. Tingey, S. Flingai, D. O. Villarreal, M. Wise, A. Patel, A. Izmirly, A. Aljuaid, A. M. Seliga, G. Soule, M. Morrow, K. A. Kraynyak, A. S. Khan, D. P. Scott, F. Feldmann, R. LaCasse, K. Meade-White, A. Okumura, K. E. Ugen, N. Y. Sardesai, J. J. Kim, G. Kobinger, H. Feldmann, D. B. Weiner, A synthetic consensus anti-spike protein DNA vaccine induces protective immunity against Middle East respiratory syndrome coronavirus in nonhuman primates. Sci. Transl. Med. 7, 301ra132 (2015). doi:10.1126/scitransImed.aac7462 Medline

56. J. Lan, Y. Yao, Y. Deng, H. Chen, G. Lu, W. Wang, L. Bao, W. Deng, Q. Wei, G. F. Gao,
C. Qin, W. Tan, Recombinant Receptor Binding Domain Protein Induces Partial Protective Immunity in Rhesus Macaques Against Middle East Respiratory Syndrome Coronavirus Challenge. EBioMedicine 2, 1438-1446 (2015). doi:10.1016/j.ebiom.2015.08.031 Medline

57. L. Wang, W. Shi, M. G. Joyce, K. Modjarrad, Y. Zhang, K. Leung, C. R. Lees, T. Zhou, H. M. Yassine, M. Kanekiyo, Z. Y. Yang, X. Chen, M. M. Becker, M. Freeman, L. Vogel, J. C. Johnson, G. Olinger, J. P. Todd, U. Bagci, J. Solomon, D. J. Mollura, L. Hensley, P. Jahrling, M. R. Denison, S. S. Rao, K. Subbarao, P. D. Kwong, J. R. Mascola, W.-P. Kong, B. S. Graham, Evaluation of candidate vaccine approaches for MERS-CoV. Nat. Commun. 6, 7712 (2015). doi:10.1038/ncomms8712 Medline

58. M. Jaume, M. S. Yip, C. Y. Cheung, H. L. Leung, P. H. Li, F. Kien, I. Dutry, B. Callendret, N. Escriou, R. Altmeyer, B. Nal, M. Daëron, R. Bruzzone, J. S. M. Peiris, Anti-severe acute respiratory syndrome coronavirus spike antibodies trigger infection of human immune cells via a $\mathrm{pH}$ - and cysteine protease-independent FçR pathway. J. Virol. 85, 10582-10597 (2011). doi:10.1128/JVl.00671-11 Medline

59. M. K. Smatti, A. A. Al Thani, H. M. Yassine, Viral-Induced Enhanced Disease Illness. Front. Microbiol. 9, 2991 (2018). doi:10.3389/fmicb.2018.02991 Medline

60. S. F. Wang, S.-P. Tseng, C.-H. Yen, J.-Y. Yang, C.-H. Tsao, C.-W. Shen, K.-H. Chen, F.-T. Liu, W.-T. Liu, Y.-M. A. Chen, J. C. Huang, Antibody-dependent SARS coronavirus infection is mediated by antibodies against spike proteins. Biochem. Biophys. Res. Commun. 451, 208-214 (2014). doi:10.1016/i.bbrc.2014.07.090 Medline

61. N. C. Pedersen, H. Liu, J. Scarlett, C. M. Leutenegger, L. Golovko, H. Kennedy, F. M. Kamal, Feline infectious peritonitis: Role of the feline coronavirus $3 c$ gene in intestinal tropism and pathogenicity based upon isolates from resident and adopted shelter cats. Virus Res. 165, 17-28 (2012). doi:10.1016/i.virusres.2011.12.020 Medline

62. Y. Wan, J. Shang, S. Sun, W. Tai, J. Chen, Q. Geng, L. He, Y. Chen, J. Wu, Z. Shi, Y. Zhou, L. Du, F. Li, Molecular Mechanism for Antibody-Dependent Enhancement of Coronavirus Entry. J. Virol. 94, ・. (2020). Medline

63. K. V. Houser, A. J. Broadbent, L. Gretebeck, L. Vogel, E. W. Lamirande, T. Sutton, K. W. Bock, M. Minai, M. Orandle, I. N. Moore, K. Subbarao, Enhanced inflammation in New Zealand white rabbits when MERS-CoV reinfection occurs in the absence of neutralizing antibody. PLOS Pathog. 13, e1006565 (2017). doi:10.1371/journal.ppat.1006565 Medline

64. A. S. Agrawal, X. Tao, A. Algaissi, T. Garron, K. Narayanan, B.-H. Peng, R. B. Couch, C.-T. K. Tseng, Immunization with inactivated Middle East Respiratory Syndrome coronavirus vaccine leads to lung immunopathology on challenge with live virus. Hum. Vaccin. Immunother. 12, 2351-2356 (2016) doi:10.1080/21645515.2016.1177688 Medline

65. E. G. Severance, I. Bossis, F. B. Dickerson, C. R. Stallings, A. E. Origoni, A. Sullens, R. H. Yolken, R. P. Viscidi, Development of a nucleocapsid-based human coronavirus immunoassay and estimates of individuals exposed to coronavirus in a U.S. metropolitan population. Clin. Vaccine Immunol. 15, 1805-1810 (2008). doi:10.1128/CVI.00124-08 Medline

66. K. A. Callow, H. F. Parry, M. Sergeant, D. A. Tyrrell, The time course of the immune response to experimental coronavirus infection of man. Epidemiol. Infect. 105, 435-446 (1990). doi:10.1017/S0950268800048019 Medline

67. K. A. Callow, Effect of specific humoral immunity and some non-specific factors on resistance of volunteers to respiratory coronavirus infection. J. Hyg. (Lond.) 95 , 173-189 (1985). doi:10.1017/S0022172400062410 Medline

68. K. Ng et al., Pre-existing and de novo humoral immunity to SARS-CoV-2 in humans. 2020 (10.1101/2020.05.14.095414\% J bioRxiv).

69. A. Z. Wec et al., Broad sarbecovirus neutralizing antibodies define a key site of vulnerability on the SARS-CoV-2 spike protein. 2020 (10.1101/2020.05.15.096511\% J bioRxiv).

70. J. Braun et al., Presence of SARS-CoV-2 reactive T cells in COVID-19 patients and healthy donors. 2020 (10.1101/2020.04.17.20061440\% J medRxiv).

71. A. Grifoni, D. Weiskopf, S. I. Ramirez, J. Mateus, J. M. Dan, C. R. Moderbacher, S. A. Rawlings, A. Sutherland, L. Premkumar, R. S. Jadi, D. Marrama, A. M. de Silva, A. Frazier, A. F. Carlin, J. A. Greenbaum, B. Peters, F. Krammer, D. M. Smith, S. Crotty, A. Sette, Targets of T Cell Responses to SARS-CoV-2 Coronavirus in Humans with COVID-19 Disease and Unexposed Individuals. Cell 181, 14891501.e15 (2020). doi:10.1016/i.cell.2020.05.015 Medline 
72. P. G. Choe, R. A. P. M. Perera, W. B. Park, K.-H. Song, J. H. Bang, E. S. Kim, H. B. Kim, L. W. R. Ko, S. W. Park, N.-J. Kim, E. H. Y. Lau, L. L. M. Poon, M. Peiris, M. D. Oh, MERS-CoV Antibody Responses 1 Year after Symptom Onset, South Korea, 2015. Emerg. Infect. Dis. 23, 1079-1084 (2017). doi:10.3201/eid2307.170310 Medline

73. J. H. Ko, M. A. Müller, H. Seok, G. E. Park, J. Y. Lee, S. Y. Cho, Y. E. Ha, J. Y. Baek, S. H. Kim, J.-M. Kang, Y.-J. Kim, I. J. Jo, C. R. Chung, M.-J. Hahn, C. Drosten, C.-I. Kang, D. R. Chung, J.-H. Song, E.-S. Kang, K. R. Peck, Serologic responses of 42 MERS-coronavirus-infected patients according to the disease severity. Diagn. Microbiol. Infect. Dis. 89, 106-111 (2017). doi:10.1016/j,diagmicrobio.2017.07.006 Medline

74. N. M. A. Okba, V. S. Raj, I. Widjaja, C. H. GeurtsvanKessel, E. de Bruin, F. D. Chandler, W. B. Park, N.-J. Kim, E. A. B. A. Farag, M. Al-Hajri, B.-J. Bosch, M. D. Oh, M. P. G. Koopmans, C. B. E. M. Reusken, B. L. Haagmans, Sensitive and Specific Detection of Low-Level Antibody Responses in Mild Middle East Respiratory Syndrome Coronavirus Infections. Emerg. Infect. Dis. 25, 1868-1877 (2019). doi:10.3201/eid2510.190051 Medline

75. A. N. Alshukairi, I. Khalid, W. A. Ahmed, A. M. Dada, D. T. Bayumi, L. S. Malic, S Althawadi, K. Ignacio, H. S. Alsalmi, H. M. Al-Abdely, G. Y. Wali, I. A. Qushmaq, B. M. Alraddadi, S. Perlman, Antibody Response and Disease Severity in Healthcare Worker MERS Survivors. Emerg. Infect. Dis. 22, 1113-1115 (2016). doi:10.3201/eid2206.160010 Medline

76. C. K. Li, H. Wu, H. Yan, S. Ma, L. Wang, M. Zhang, X. Tang, N. J. Temperton, R. A. Weiss, J. M. Brenchley, D. C. Douek, J. Mongkolsapaya, B.-H. Tran, C. L. Lin, G. R. Screaton, J. L. Hou, A. J. McMichael, X.-N. Xu, T cell responses to whole SARS coronavirus in humans. J. Immunol. 181, 5490-5500 (2008). doi:10.4049/iimmunol.181.8.5490 Medline

77. P. R. Hsueh, C.-H. Hsiao, S.-H. Yeh, W.-K. Wang, P.-J. Chen, J.-T. Wang, S.-C. Chang, C.-L. Kao, P.-C. Yang; SARS Research Group of National Taiwan University College of Medicine and National Taiwan University Hospital, Microbiologic characteristics, serologic responses, and clinical manifestations in severe acute respiratory syndrome, Taiwan. Emerg. Infect. Dis. 9, 1163-1167 (2003). doi:10.3201/eid0909.030367 Medline

78. K. H. Chan, V. C. C. Cheng, P. C. Y. Woo, S. K. P. Lau, L. L. M. Poon, Y. Guan, W. H. Seto, K. Y. Yuen, J. S. M. Peiris, Serological responses in patients with severe acute respiratory syndrome coronavirus infection and cross-reactivity with human coronaviruses 229E, OC43, and NL63. Clin. Diagn. Lab. Immunol. 12, 1317-1321 (2005). doi:10.1128/CDLI.12.11.1317-1321.2005 Medline

79. J. S. Peiris, C. M. Chu, V. C. C. Cheng, K. S. Chan, I. F. N. Hung, L. L. M. Poon, K. I Law, B. S. F. Tang, T. Y. W. Hon, C. S. Chan, K. H. Chan, J. S. C. Ng, B. J. Zheng, W. L. Ng, R. W. M. Lai, Y. Guan, K. Y. Yuen; HKU/UCH SARS Study Group, Clinical progression and viral load in a community outbreak of coronavirus-associated SARS pneumonia: A prospective study. Lancet 361, 1767-1772 (2003). doi:10.1016/S0140-6736(03)13412-5 Medline

80. P. R. Grant, J. A. Garson, R. S. Tedder, P. K. S. Chan, J. S. Tam, J. J. Y. Sung, Detection of SARS coronavirus in plasma by real-time RT-PCR. N. Engl. J. Med. 349, 2468-2469 (2003). doi:10.1056/NEJM200312183492522 Medline

81. N. J. Temperton, P. K. Chan, G. Simmons, M. C. Zambon, R. S. Tedder, Y. Takeuchi, R. A. Weiss, Longitudinally profiling neutralizing antibody response to SARS coronavirus with pseudotypes. Emerg. Infect. Dis. 11, 411-416 (2005). doi:10.3201/eid1103.040906 Medline

82. J. Zhao, J. Zhao, A. K. Mangalam, R. Channappanavar, C. Fett, D. K. Meyerholz, S. Agnihothram, R. S. Baric, C. S. David, S. Perlman, Airway Memory CD4(+) T Cells Mediate Protective Immunity against Emerging Respiratory Coronaviruses. Immunity 44, 1379-1391 (2016). doi:10.1016/i.immuni.2016.05.006 Medline

83. W. Tan et al., Viral Kinetics and Antibody Responses in Patients with COVID-19. $2020(10.1101 / 2020.03 .24 .20042382 \%$ J medRxiv).

84. D. Laczkó, M. J. Hogan, S. A. Toulmin, P. Hicks, K. Lederer, B. T. Gaudette, D. Castaño, F. Amanat, H. Muramatsu, T. H. Oguin 3rd, A. Ojha, L. Zhang, Z. Mu, R. Parks, T. B. Manzoni, B. Roper, S. Strohmeier, I. Tombácz, L. Arwood, R. Nachbagauer, K. Karikó, J. Greenhouse, L. Pessaint, M. Porto, T. Putman-Taylor, A. Strasbaugh, T.-A. Campbell, P. J. C. Lin, Y. K. Tam, G. D. Sempowski, M. Farzan, H. Choe, K. O. Saunders, B. F. Haynes, H. Andersen, L. C. Eisenlohr, D. Weissman, F. Krammer, P. Bates, D. Allman, M. Locci, N. Pardi, A Single Immunization with Nucleoside-Modified mRNA Vaccines Elicits Strong Cellular and Humoral Immune
Responses against SARS-CoV-2 in Mice. Immunity 53, 724-732.e7 (2020). doi:10.1016/i.immuni.2020.07.019 Medline

85. F. Wu et al., Neutralizing antibody responses to SARS-CoV-2 in a COVID-19 recovered patient cohort and their implications. 2020 (10.1101/2020.03.30.20047365\%」 medRxiv).

86. K. K. To, O. T.-Y. Tsang, W.-S. Leung, A. R. Tam, T.-C. Wu, D. C. Lung, C. C.-Y. Yip, J.-P. Cai, J. M.-C. Chan, T. S.-H. Chik, D. P.-L. Lau, C. Y.-C. Choi, L.-L. Chen, W.-M. Chan, K.-H. Chan, J. D. Ip, A. C.-K. Ng, R. W.-S. Poon, C.-T. Luo, V. C.-C. Cheng, J. F.-W. Chan, I. F.-N. Hung, Z. Chen, H. Chen, K.-Y. Yuen, Temporal profiles of viral load in posterior oropharyngeal saliva samples and serum antibody responses during infection by SARS-CoV-2: An observational cohort study. Lancet Infect. Dis. 20, 565-574 (2020). doi:10.1016/S1473-3099(20)30196-1 Medline

87. J. Ou et al., Study on the expression levels of antibodies against SARS-CoV-2 at different period of disease and its related factors in 192 cases of COVID-19 patients. 2020 (10.1101/2020.05.22.20102525\% J medRxiv).

88. C. Cervia et al., Systemic and mucosal antibody secretion specific to SARS-CoV-2 during mild versus severe COVID-19. 2020 (10.1101/2020.05.21.108308\%」 bioRxiv).

89. Y. Liu, L.-M. Yan, L. Wan, T.-X. Xiang, A. Le, J.-M. Liu, M. Peiris, L. L. M. Poon, W. Zhang, Viral dynamics in mild and severe cases of COVID-19. Lancet Infect. Dis. 20, 656-657 (2020). doi:10.1016/S1473-3099(20)30232-2 Medline

90. A. Weiss, M. Jellings $\varnothing$, M. O. A. Sommer, Spatial and temporal dynamics of SARSCoV-2 in COVID-19 patients: A systematic review and meta-analysis. EBioMedicine 58, 102916 (2020). doi:10.1016/i.ebiom.2020.102916 Medline

91. K. V. Argyropoulos, A. Serrano, J. Hu, M. Black, X. Feng, G. Shen, M. Call, M. J. Kim, A. Lytle, B. Belovarac, T. Vougiouklakis, L. H. Lin, U. Moran, A. Heguy, A. Troxel, M. Snuderl, I. Osman, P. Cotzia, G. Jour, Association of Initial Viral Load in Severe Acute Respiratory Syndrome Coronavirus 2 (SARS-CoV-2) Patients with Outcome and Symptoms. Am. J. Pathol. 190, 1881-1887 (2020). doi:10.1016/i.aipath.2020.07.001 Medline

92. R. Tillett et al., Genomic Evidence for a Case of Reinfection with SARS-CoV-2, SSRN (2020). 10.2139/ssrn.3680955

93. F. Calabrese, F. Pezzuto, F. Fortarezza, P. Hofman, I. Kern, A. Panizo, J. von der Thüsen, S. Timofeev, G. Gorkiewicz, F. Lunardi, Pulmonary pathology and COVID19: Lessons from autopsy. The experience of European Pulmonary Pathologists. Virchows Arch. 477, 359-372 (2020). Medline

94. R. B. Martines, J. M. Ritter, E. Matkovic, J. Gary, B. C. Bollweg, H. Bullock, C. S. Goldsmith, L. Silva-Flannery, J. N. Seixas, S. Reagan-Steiner, T. Uyeki, A. Denison, J. Bhatnagar, W.-J. Shieh, S. R. Zaki; COVID-19 Pathology Working Group, Pathology and Pathogenesis of SARS-CoV-2 Associated with Fatal Coronavirus Disease, United States. Emerg. Infect. Dis. 26, 2005-2015 (2020). doi:10.3201/eid2609.202095 Medline

95. M. Merad, J. C. Martin, Pathological inflammation in patients with COVID-19: A key role for monocytes and macrophages. Nat. Rev. Immunol. 20, 355-362 (2020). doi:10.1038/s41577-020-0331-4 Medline

96. G. Chen, D. Wu, W. Guo, Y. Cao, D. Huang, H. Wang, T. Wang, X. Zhang, H. Chen, H. Yu, X. Zhang, M. Zhang, S. Wu, J. Song, T. Chen, M. Han, S. Li, X. Luo, J. Zhao, Q. Ning, Clinical and immunological features of severe and moderate coronavirus disease 2019. J. Clin. Invest. 130, 2620-2629 (2020). doi:10.1172/JCl137244 Medline

97. A. G. Laing et al., A consensus Covid-19 immune signature combines immunoprotection with discrete sepsis-like traits associated with poor prognosis. 2020 (10.1101/2020.06.08.20125112\% J medRxiv).

98. R. Channappanavar, S. Perlman, Pathogenic human coronavirus infections: Causes and consequences of cytokine storm and immunopathology. Semin. Immunopathol. 39, 529-539 (2017). doi:10.1007/s00281-017-0629-x Medline

99. A. R. Fehr, R. Channappanavar, S. Perlman, Middle East Respiratory Syndrome: Emergence of a Pathogenic Human Coronavirus. Annu. Rev. Med. 68, 387-399 (2017). doi:10.1146/annurev-med-051215-031152 Medline

100. P. S. Arunachalam, F. Wimmers, C. K. P. Mok, R. A. P. M. Perera, M. Scott, T. Hagan, N. Sigal, Y. Feng, L. Bristow, O. Tak-Yin Tsang, D. Wagh, J. Coller, K. L. Pellegrini, D. Kazmin, G. Alaaeddine, W. S. Leung, J. M. C. Chan, T. S. H. Chik, C. Y C. Choi, C. Huerta, M. Paine McCullough, H. Lv, E. Anderson, S. Edupuganti, A. A. Upadhyay, S. E. Bosinger, H. T. Maecker, P. Khatri, N. Rouphael, M. Peiris, B. Pulendran, Systems biological assessment of immunity to mild versus severe 
COVID-19 infection in humans. Science 369, 1210-1220 (2020). doi:10.1126/science. abc6261 Medline

101. C. Lucas, P. Wong, J. Klein, T. B. R. Castro, J. Silva, M. Sundaram, M. K. Ellingson, T. Mao, J. E. Oh, B. Israelow, T. Takahashi, M. Tokuyama, P. Lu, A. Venkataraman, A. Park, S. Mohanty, H. Wang, A. L. Wyllie, C. B. F. Vogels, R. Earnest, S. Lapidus, I. M. Ott, A. J. Moore, M. C. Muenker, J. B. Fournier, M. Campbell, C. D. Odio, A. Casanovas-Massana, R. Herbst, A. C. Shaw, R. Medzhitov, W. L. Schulz, N. D. Grubaugh, C. Dela Cruz, S. Farhadian, A. I. Ko, S. B. Omer, A. Iwasaki; Yale IMPACT Team, Longitudinal analyses reveal immunological misfiring in severe COVID-19. Nature 584, 463-469 (2020). doi:10.1038/s41586-020-2588-y Medline

102. J. B. Moore, C. H. June, Cytokine release syndrome in severe COVID-19. Science 368, 473-474 (2020). doi:10.1126/science.abb8925 Medline

103. K. Modjarrad, C. C. Roberts, K. T. Mills, A. R. Castellano, K. Paolino, K. Muthumani, E. L. Reuschel, M. L. Robb, T. Racine, M. D. Oh, C. Lamarre, F. I. Zaidi, J. Boyer, S. B. Kudchodkar, M. Jeong, J. M. Darden, Y. K. Park, P. T. Scott, C. Remigio, A. P. Parikh, M. C. Wise, A. Patel, E. K. Duperret, K. Y. Kim, H. Choi, S. White, M. Bagarazzi, J. M. May, D. Kane, H. Lee, G. Kobinger, N. L. Michael, D. B. Weiner, S. J. Thomas, J. N. Maslow, Safety and immunogenicity of an anti-Middle East respiratory syndrome coronavirus DNA vaccine: A phase 1 , open-label, singlearm, dose-escalation trial. Lancet Infect. Dis. 19, 1013-1022 (2019). doi:10.1016/S1473-3099(19)30266-X Medline

104. T. Koch, C. Dahlke, A. Fathi, A. Kupke, V. Krähling, N. M. A. Okba, S. Halwe, C. Rohde, M. Eickmann, A. Volz, T. Hesterkamp, A. Jambrecina, S. Borregaard, M. L. Ly, M. E. Zinser, E. Bartels, J. S. H. Poetsch, R. Neumann, R. Fux, S. Schmiedel, A. W. Lohse, B. L. Haagmans, G. Sutter, S. Becker, M. M. Addo, Safety and immunogenicity of a modified vaccinia virus Ankara vector vaccine candidate for Middle East respiratory syndrome: An open-label, phase 1 trial. Lancet Infect. Dis. 20, 827-838 (2020). doi:10.1016/S1473-3099(20)30248-6 Medline

105. P. M. Folegatti, M. Bittaye, A. Flaxman, F. R. Lopez, D. Bellamy, A. Kupke, C. Mair, R. Makinson, J. Sheridan, C. Rohde, S. Halwe, Y. Jeong, Y.-S. Park, J.-O. Kim, M. Song, A. Boyd, N. Tran, D. Silman, I. Poulton, M. Datoo, J. Marshall, Y. Themistocleous, A. Lawrie, R. Roberts, E. Berrie, S. Becker, T. Lambe, A. Hill, K. Ewer, S. Gilbert, Safety and immunogenicity of a candidate Middle East respiratory syndrome coronavirus viral-vectored vaccine: A dose-escalation, open-label, non-randomised, uncontrolled, phase 1 trial. Lancet Infect. Dis. 20, 816-826 (2020). doi:10.1016/S1473-3099(20)30160-2 Medline

106. J. T. Lin, J. S. Zhang, N. Su, J. G. Xu, N. Wang, J. T. Chen, X. Chen, Y. X. Liu, H. Gao, Y. P. Jia, Y. Liu, R. H. Sun, X. Wang, D. Z. Yu, R. Hai, Q. Gao, Y. Ning, H. X. Wang, M. C. Li, B. Kan, G. M. Dong, Q. An, Y. Q. Wang, J. Han, C. Qin, W. D. Yin, X. P. Dongs, Safety and immunogenicity from a phase I trial of inactivated severe acute respiratory syndrome coronavirus vaccine. Antivir. Ther. 12, 1107-1113 (2007). Medline

107. J. E. Martin, M. K. Louder, L. A. Holman, I. J. Gordon, M. E. Enama, B. D. Larkin, C. A. Andrews, L. Vogel, R. A. Koup, M. Roederer, R. T. Bailer, P. L. Gomez, M. Nason, J. R. Mascola, G. J. Nabel, B. S. Graham; VRC 301 Study Team, A SARS DNA vaccine induces neutralizing antibody and cellular immune responses in healthy adults in a Phase I clinical trial. Vaccine 26, 6338-6343 (2008). doi:10.1016/i.vaccine.2008.09.026 Medline

108. P. M. Folegatti, K. J. Ewer, P. K. Aley, B. Angus, S. Becker, S. Belij-Rammerstorfer, D. Bellamy, S. Bibi, M. Bittaye, E. A. Clutterbuck, C. Dold, S. N. Faust, A. Finn, A. L. Flaxman, B. Hallis, P. Heath, D. Jenkin, R. Lazarus, R. Makinson, A. M. Minassian, K. M. Pollock, M. Ramasamy, H. Robinson, M. Snape, R. Tarrant, M. Voysey, C. Green, A. D. Douglas, A. V. S. Hill, T. Lambe, S. C. Gilbert, A. J. Pollard; Oxford COVID Vaccine Trial Group, Safety and immunogenicity of the ChAdOx1 nCoV-19 vaccine against SARS-CoV-2: A preliminary report of a phase 1/2, single-blind, randomised controlled trial. Lancet 396, 467-478 (2020). doi:10.1016/S01406736(20)31604-4 Medline

109. F. C. Zhu, Y.-H. Li, X.-H. Guan, L.-H. Hou, W.-J. Wang, J.-X. Li, S.-P. Wu, B.-S. Wang, Z. Wang, L. Wang, S.-Y. Jia, H.-D. Jiang, L. Wang, T. Jiang, Y. Hu, J.-B. Gou, S.-B. $\mathrm{Xu}$, J.-J. Xu, X.-W. Wang, W. Wang, W. Chen, Safety, tolerability, and immunogenicity of a recombinant adenovirus type- 5 vectored COVID-19 vaccine: A dose-escalation, open-label, non-randomised, first-in-human trial. Lancet 395 , 1845-1854 (2020). doi:10.1016/S0140-6736(20)31208-3 Medline

110. M. J. Mulligan et al., Phase $1 / 2$ Study to Describe the Safety and Immunogenicity of a COVID-19 RNA Vaccine Candidate (BNT162b1) in Adults 18 to 55 Years of Age:
Interim Report. 2020 (10.1101/2020.06.30.20142570\% J medRxiv).

111. L. A. Jackson, E. J. Anderson, N. G. Rouphael, P. C. Roberts, M. Makhene, R. N. Coler, M. P. McCullough, J. D. Chappell, M. R. Denison, L. J. Stevens, A. J. Pruijssers, A. McDermott, B. Flach, N. A. Doria-Rose, K. S. Corbett, K. M. Morabito, S. O'Dell, S. D. Schmidt, P. A. Swanson 2nd, M. Padilla, J. R. Mascola, K. M. Neuzil, H. Bennett, W. Sun, E. Peters, M. Makowski, J. Albert, K. Cross, W. Buchanan, R. Pikaart-Tautges, J. E. Ledgerwood, B. S. Graham, J. H. Beigel; mRNA-1273 Study Group, An mRNA Vaccine against SARS-CoV-2 - Preliminary Report. N. Engl. J. Med. NEJMoa2022483 (2020). doi:10.1056/NEJMoa2022483 Medline

112. S. Mallapaty, H. Ledford, COVID-vaccine results are on the way - and scientists' concerns are growing. Nature 586, 16-17 (2020). doi:10.1038/d41586-02002706-6 Medline

113. D. Grady, K. J. Wu, S. LaFraniere, AstraZeneca, Under Fire for Vaccine Safety, Releases Trial Blueprints, The New York Times. (2020).

114. M. J. Joyner et al., Effect of Convalescent Plasma on Mortality among Hospitalized Patients with COVID-19: Initial Three-Month Experience. 2020 (10.1101/2020.08.12.20169359\% J medRxiv).

115. S. T. H. Liu et al., Convalescent plasma treatment of severe COVID-19: A matched control study. 2020 (10.1101/2020.05.20.20102236\% J medRxiv).

116. R. C. Becker, COVID-19 update: Covid-19-associated coagulopathy. J. Thromb. Thrombolysis 50, 54-67 (2020). doi:10.1007/s11239-020-02134-3 Medline

117. M. Slaoui, M. Hepburn, Developing Safe and Effective Covid Vaccines - Operation Warp Speed's Strategy and Approach. N. Engl. J. Med. NEJMp2027405 (2020). doi:10.1056/NEJMp2027405 Medline

118. U.S. Department of Health and Human Services, Food and Drug Administration, and Center for Biologics Evalation and Research, Development and Licensure of Vaccines to Prevent COVID-19: Guidance for Industry (2020 https://www.fda.gov/regulatory-information/search-fda-guidancedocuments/development-and-licensure-vaccines-prevent-covid-19).

119. Emergency Use Authorization for Vaccines to Prevent COVID-19: Guidance for Industry (2020 https://www.fda.gov/regulatory-information/search-fdaguidance-documents/emergency-use-authorization-vaccines-prevent-covid19).

120. C. Zimmer, K. Thomas, B. Mueller, "AstraZeneca Partly Resumes Coronavirus Vaccine Trial After Halting It for Safety," New York Times, 12 September 2020.

121. N. Phillips, D. Cyranoski, S. Mallapaty, A leading coronavirus vaccine trial is on hold: Scientists react. Nature News 10.1038/d41586-020-02594-w (2020). doi:10.1038/d41586-020-02594-w Medline

122. N. A. Halsey, K. M. Edwards, C. L. Dekker, N. P. Klein, R. Baxter, P. Larussa, C. Marchant, B. Slade, C. Vellozzi; Causality Working Group of the Clinical Immunization Safety Assessment network, Algorithm to assess causality after individual adverse events following immunizations. Vaccine 30, 5791-5798 (2012). doi:10.1016/j.vaccine.2012.04.005 Medline

123. M. E. Deming, N. L. Michael, M. Robb, M. S. Cohen, K. M. Neuzil, Accelerating Development of SARS-CoV-2 Vaccines - The Role for Controlled Human Infection Models. N. Engl. J. Med. 383, e63 (2020). doi:10.1056/NEJMp2020076 Medline

124. H. Weingartl, M. Czub, S. Czub, J. Neufeld, P. Marszal, J. Gren, G. Smith, S. Jones, R. Proulx, Y. Deschambault, E. Grudeski, A. Andonov, R. He, Y. Li, J. Copps, A. Grolla, D. Dick, J. Berry, S. Ganske, L. Manning, J. Cao, Immunization with modified vaccinia virus Ankara-based recombinant vaccine against severe acute respiratory syndrome is associated with enhanced hepatitis in ferrets. J. Virol. 78 , 12672-12676 (2004). doi:10.1128/JVI.78.22.12672-12676.2004 Medline

125. K. Duan, B. Liu, C. Li, H. Zhang, T. Yu, J. Qu, M. Zhou, L. Chen, S. Meng, Y. Hu, C. Peng, M. Yuan, J. Huang, Z. Wang, J. Yu, X. Gao, D. Wang, X. Yu, L. Li, J. Zhang, X. Wu, B. Li, Y. Xu, W. Chen, Y. Peng, Y. Hu, L. Lin, X. Liu, S. Huang, Z. Zhou, L. Zhang, Y. Wang, Z. Zhang, K. Deng, Z. Xia, Q. Gong, W. Zhang, X. Zheng, Y. Liu, H. Yang, D. Zhou, D. Yu, J. Hou, Z. Shi, S. Chen, Z. Chen, X. Zhang, X. Yang, Effectiveness of convalescent plasma therapy in severe COVID-19 patients. Proc. Natl. Acad. Sci. U.S.A. 117, 9490-9496 (2020). doi:10.1073/pnas.2004168117 Medline

Acknowledgments: The authors acknowledge Tom Shimabukuro and Nancy Messonnier of the U.S. Centers for Disease Control and Prevention for helpful discussions, and Whitney Edwards of the Duke Human Vaccine Institute and Brett Tolman of Deloitte Consulting LLP for editorial assistance. We thank the ACTIV Working Group whose nonauthor members include: Paula Annunziato, Merck \& Co., Inc.; Beth Bell, University of Washington; Susan Buchbinder, 
University of California, San Francisco and San Francisco Department of Public Health; Marco Cavaleri, European Medicines Agency; Mark Davis, Stanford University School of Medicine; Emilio Emini, Bill \& Melinda Gates Foundation; Gregory Glenn, Novavax, Inc.; Emmanuel Hanon, GlaxoSmithKline; Kathrin Jansen, Pfizer; Antonio Lanzavecchia, Vir Biotechnology, Inc and Institute for Research in Biomedicine; Douglas Lowy, National Cancer Institute, NIH; Peter Marks, U.S. Food and Drug Administration; John Mascola, National Institute of Allergy and Infectious Diseases, NIH; Nancy Messonnier, U.S. Centers for Disease Control and Prevention; Nelson Michael, Walter Reed Army Institute of Research; Paul Offit, University of Pennsylvania; Jonathan Seals, Biomedical Advanced Research and Development Authority, Health and Human Services; Jim Tartaglia, Sanofi Pasteur; Tonya Villafana, AstraZeneca; Tal Zaks, Moderna, Inc. Competing interests: BFH is a coinventor on patent applications for COVID19 vaccine designs. PJH is developing a low cost COVID-19 vaccine that has been licensed to a pharmaceutical company for manufacture. SR is currently employed by Sanofi, which is pursuing therapeutic and vaccine development to treat COVID-19. HS is an employee and shareholder of Johnson \& Johnson, which is developing a COVID-19 vaccine. MW is currently employed by Moderna, Inc., which is pursuing therapeutic and vaccine development to treat COVID-19. $\mathrm{AA}$ is a consultant for Vir Biotechnology. The other authors declare no competing interests.

Published First Release 19 October 2020

10.1126/scitranslmed.abe0948 


\section{Antibody-dependent enhancement}

Virion phagocytosis

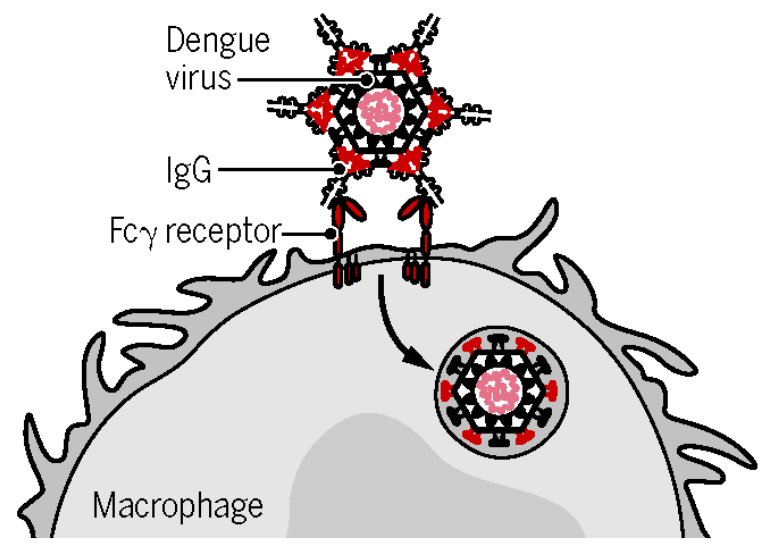

Viral immune evasion

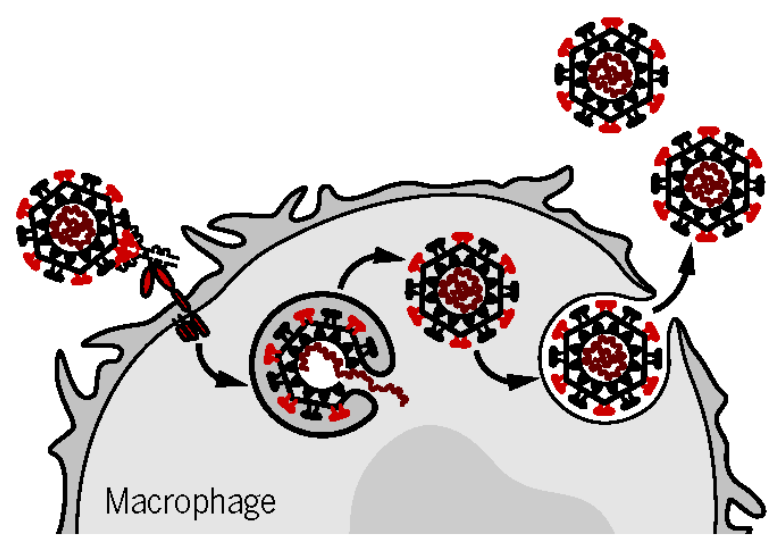

\section{Vaccine-associated enhancement}

Immune complex deposition

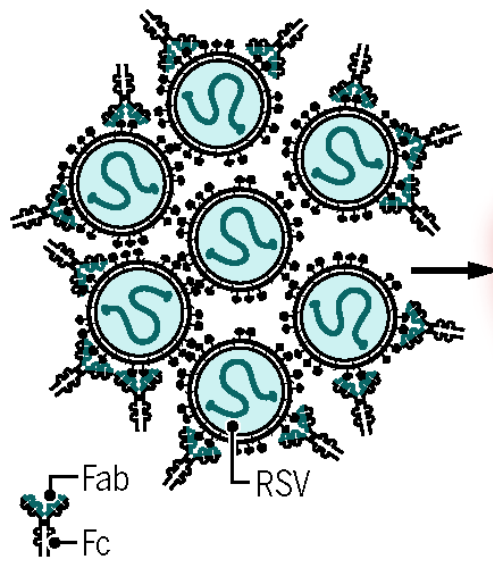

Th2 biased $C D 4^{+} \mathrm{T}$ cell response

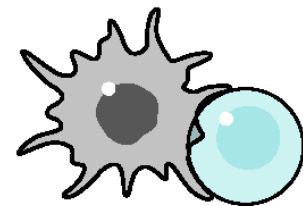

RSV antigen Naive presenting Tcell

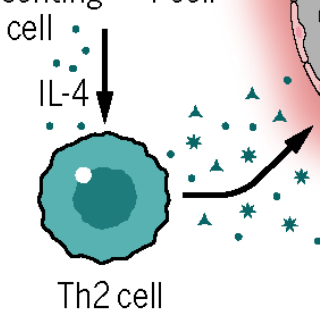

IL-4. IL-13. IL-5

Fig. 1. Immune enhancement of human viral disease. Immune enhancement of human viral disease through viral re-infection or vaccination has been documented in (top) natural dengue virus infection and (bottom) vaccination with a formalin-inactivated vaccine for RSV. (Top) During natural dengue virus infection, IgG antibodies protect against dengue virus of one serotype by causing uptake of virus particles and their degradation when the Fab fragment of IgG binds to a surface viral protein and the Fc portion of IgG binds to Fcy receptors expressed by macrophages and other immune cells. A second infection with a different dengue virus serotype creates a risk of antibody-dependent enhancement of disease because cross-reactive antibodies against the first serotype that have limited neutralizing capacity can mediate internalization of the virus by Fcy receptor-bearing cells. Viral immune evasion mechanisms then allow the production and release of new virions. (Bottom) Vaccineassociated enhancement of disease (VAED) occurred in some children given a formalin-inactivated RSV vaccine in the 1960s. Although the immunological mechanisms of VAED remain undefined, fatal RSV infection occurred in two children after vaccination and was associated with complement activation. This was attributed to the formation of immune complexes and their deposition in the lungs, and peribronchiolitis and alveolitis associated with pulmonary infiltration by neutrophils and eosinophils, which is consistent with a Th2-biased CD4 ${ }^{+} \mathrm{T}_{\text {cell }}$ response. 
Table 1. Immune enhancement of coronavirus disease in animal models.

\begin{tabular}{|c|c|c|c|c|c|c|}
\hline Virus & $\begin{array}{l}\text { Infection or } \\
\text { Vaccine }\end{array}$ & $\begin{array}{l}\text { Animal } \\
\text { Model }\end{array}$ & $\begin{array}{l}\text { Immune enhance- } \\
\text { ment of disease af- } \\
\text { ter virus exposure }\end{array}$ & $\begin{array}{l}\text { Virus neutraliz- } \\
\text { ing antibody } \\
\text { (VNA) titers }\end{array}$ & Reference & Notes \\
\hline \multirow[t]{4}{*}{$\begin{array}{l}\text { SARS- } \\
\text { CoV-2 }\end{array}$} & $\begin{array}{l}\text { Infection with } \\
\text { live virus }\end{array}$ & $\begin{array}{l}\text { Rhesus } \\
\text { macaques }\end{array}$ & No & $\begin{array}{l}83-197 \text { by the } \\
\text { pseudovirus } \\
\text { neutralization } \\
\text { assay; } 35-326 \\
\text { by the live vi- } \\
\text { rus neutraliza- } \\
\text { tion assay }\end{array}$ & $(31,32)$ & \multirow[t]{4}{*}{$\begin{array}{l}\text { Following virus } \\
\text { reinfection }\end{array}$} \\
\hline & DNA vaccine & $\begin{array}{l}\text { Rhesus } \\
\text { macaques }\end{array}$ & No & Median titer, 74 & (35) & \\
\hline & $\begin{array}{l}\text { Inactivated vi- } \\
\text { rus vaccine } \\
\text { with alum }\end{array}$ & $\begin{array}{l}\text { Rhesus } \\
\text { macaques }\end{array}$ & No & $145-400$ & $(5,34)$ & \\
\hline & $\begin{array}{l}\text { Adenovirus- } \\
\text { vector vaccine }\end{array}$ & $\begin{array}{l}\text { Rhesus } \\
\text { macaques }\end{array}$ & No & $5-40$ & & \\
\hline \multirow[t]{9}{*}{$\begin{array}{l}\text { SARS- } \\
\text { CoV-1 }\end{array}$} & $\begin{array}{l}\text { Infection with } \\
\text { live virus }\end{array}$ & Ferrets & No & $720-800 \mathrm{U}$ & (43) & $\begin{array}{l}\text { Following virus } \\
\text { reinfection }\end{array}$ \\
\hline & $\begin{array}{l}\text { Infection with } \\
\text { live virus }\end{array}$ & $\begin{array}{l}\text { African } \\
\text { green } \\
\text { monkeys }\end{array}$ & Yes & $10^{2}-10^{4}$ & (44) & $\begin{array}{l}\text { Following virus } \\
\text { reinfection }\end{array}$ \\
\hline & $\begin{array}{l}\text { Modified virus } \\
\text { vaccinia An- } \\
\text { kara (MVA) } \\
\text { vector vaccine }\end{array}$ & Ferrets & Yes & $\begin{array}{l}20-40 \text { Pre-chal- } \\
\text { lenge, up to } \\
1,280 \\
\text { Post-challenge }\end{array}$ & $(46,124)$ & $\begin{array}{l}\text { No neutralizing } \\
\text { antibody in rMVA } \\
\text { expressing N pro- } \\
\text { tein }\end{array}$ \\
\hline & $\begin{array}{l}\text { Modified virus } \\
\text { vaccinia An- } \\
\text { kara (MVA) } \\
\text { vector vaccine }\end{array}$ & $\begin{array}{l}\text { Chinese } \\
\text { Rhesus } \\
\text { macaques }\end{array}$ & Yes & $10^{3}-10^{4}$ & (45) & $\begin{array}{l}\text { Immunopathology } \\
\text { associated with } \\
\text { IL-8 }\end{array}$ \\
\hline & $\begin{array}{l}\text { Recombinant } \\
\text { vaccinia vac- } \\
\text { cine }\end{array}$ & Mice & Yes & Not reported & (47) & $\begin{array}{l}\text { Immunopathology } \\
\text { associated with } \\
\text { IL-6 }\end{array}$ \\
\hline & $\begin{array}{l}\text { Dendritic cell } \\
\text { peptide immun- } \\
\text { ization with or } \\
\text { without a re- } \\
\text { combinant vac- } \\
\text { cinia virus } \\
\text { booster }\end{array}$ & Mice & No & Not reported & $(52,54)$ & $\begin{array}{l}\text { Protection associ- } \\
\text { ated with CD8+ T } \\
\text { cell responses }\end{array}$ \\
\hline & $\begin{array}{l}\text { Venezuelan eq- } \\
\text { uine encephali- } \\
\text { tis replicon }\end{array}$ & Mice & Yes/No & $\begin{array}{l}\text { PRNT }_{80} 100- \\
1,600\end{array}$ & $(48,82)$ & $\begin{array}{l}\text { Conflicting results } \\
\text { implicating viral } \\
\text { nucleoprotein }\end{array}$ \\
\hline & $\begin{array}{l}\text { Inactivated vi- } \\
\text { rus vaccine }\end{array}$ & Mice & Yes & $\begin{array}{l}\text { Geometric } \\
\text { mean neutraliz- } \\
\text { ing antibody } \\
\text { Log }_{2} 7-10 \\
\text { VNA detected } \\
\text { post-challenge } \\
\text { only }\end{array}$ & $(50,53)$ & $\begin{array}{l}\text { Immunopathology } \\
\text { with unadjuvanted } \\
\text { whole virus vac- } \\
\text { cine, despite pro- } \\
\text { tection; reduced } \\
\text { immunopathology } \\
\text { with alum }\end{array}$ \\
\hline & $\begin{array}{l}\text { Spike protein } \\
\text { and spike pro- } \\
\text { tein receptor } \\
\text { binding domain }\end{array}$ & Mice & $\begin{array}{l}\text { Yes (spike protein) } \\
\text { No (spike protein } \\
\text { receptor binding } \\
\text { domain) }\end{array}$ & $\begin{array}{l}\text { Geometric } \\
\text { mean neutraliz- } \\
\text { ing antibody } \\
\log _{2} 5-10\end{array}$ & $\begin{array}{l}(50,51, \\
53)\end{array}$ & $\begin{array}{l}\text { Conflicting results } \\
\text { with spike protein } \\
\text { (both reduced and } \\
\text { enhanced with } \\
\text { alum) }\end{array}$ \\
\hline
\end{tabular}


subunit vac-

cines
Geometric

mean neutraliz-

ing antibody

$\log _{2} 4-6$

VNA detected

post-challenge

only
Reduced immunopathology with spike protein receptor binding domain with alum

\begin{tabular}{|c|c|c|c|c|c|c|}
\hline \multirow[t]{5}{*}{$\begin{array}{l}\text { MERS } \\
\text {-CoV }\end{array}$} & DNA vaccine & $\begin{array}{l}\text { Rhesus } \\
\text { macaques }\end{array}$ & No & $\begin{array}{l}\text { Approximately } \\
10^{2}\end{array}$ & (55) & \\
\hline & $\begin{array}{l}\text { Spike protein } \\
\text { (Ribi) and re- } \\
\text { ceptor binding } \\
\text { domain subunit } \\
\text { vaccines with } \\
\text { alum }\end{array}$ & $\begin{array}{l}\text { Rhesus } \\
\text { macaques }\end{array}$ & No & $\begin{array}{l}\text { Pseudovirus in- } \\
\text { hibition }(\mathrm{PI})_{50}= \\
400-1,200\end{array}$ & $(56,57)$ & $\begin{array}{l}\text { Spike protein for- } \\
\text { mulated with } \\
\text { Ribi; receptor } \\
\text { binding domain } \\
\text { formulated with } \\
\text { alum }\end{array}$ \\
\hline & $\begin{array}{l}\text { Adenovirus } \\
\text { vector vaccine }\end{array}$ & $\begin{array}{l}\text { Rhesus } \\
\text { macaques }\end{array}$ & No & $\begin{array}{l}\text { Geometric } \\
\text { mean titer up to } \\
148\end{array}$ & & \\
\hline & $\begin{array}{l}\text { Infection with } \\
\text { live virus }\end{array}$ & $\begin{array}{l}\text { New Zea- } \\
\text { land white } \\
\text { rabbits }\end{array}$ & Yes & $\begin{array}{l}\text { Neutralizing } \\
\text { antibodies asso- } \\
\text { ciated with pro- } \\
\text { tection from } \\
\text { viral infection } \\
\text { and associated } \\
\text { pathology }\end{array}$ & (63) & $\begin{array}{l}\text { Immunopathology } \\
\text { after virus reinfec- } \\
\text { tion associated } \\
\text { with non-neutral- } \\
\text { izing antibodies, } \\
\text { complement acti- } \\
\text { vation, and CD3+ } \\
\text { T cells, but no } \\
\text { clinically discern- } \\
\text { able disease }\end{array}$ \\
\hline & $\begin{array}{l}\text { Inactivated vi- } \\
\text { rus vaccine }\end{array}$ & Mice & Yes & $\begin{array}{l}\text { Geometric } \\
\text { mean titer } \\
\log _{2} 4-6\end{array}$ & (64) & $\begin{array}{l}\text { Eosinophilic pa- } \\
\text { thology with both } \\
\text { unadjuvanted vac- } \\
\text { cine or vaccine } \\
\text { with alum or } \\
\text { MF59 }\end{array}$ \\
\hline
\end{tabular}

Table 2. Power calculation to detect an elevated rate of severe COVID-19 disease in vaccine vs. placebo recipients over 12 months, with 20,000 enrolled vaccine recipients and 10,000 enrolled placebo recipients*

\begin{tabular}{lcccccccc}
\hline & \multicolumn{3}{c}{ Hazard Ratio (Vaccine/Placebo) of } \\
& \multicolumn{3}{c}{ Severe COVID-19 } & \multicolumn{4}{c}{$\begin{array}{c}\text { Results reported if an Elevated Rate of Severe COVID- } \\
\text { 19 Disease was Just Detected *** }\end{array}$} \\
\cline { 2 - 10 } $\begin{array}{l}\text { Annual Incidence } \\
\text { in Placebo Arm** }\end{array}$ & 1.25 & 1.5 & 2.0 & 3.0 & $\begin{array}{c}\text { Expected \# } \\
\text { Placebo Cases }\end{array}$ & $\begin{array}{c}\text { \# Vaccine } \\
\text { Cases }\end{array}$ & Est. & $95 \%$ CI \\
\hline${ }^{\mathrm{a}} 0.0010$ & 0.083 & 0.183 & 0.537 & 0.959 & 10 & 40 & 2.00 & $1.01-4.00$ \\
${ }^{\mathrm{b}} 0.0020$ & 0.141 & 0.367 & 0.851 & $>0.999$ & 20 & 66 & 1.65 & $1.01-2.72$ \\
${ }^{\mathrm{c}} 0.0040$ & 0.233 & 0.629 & 0.991 & $>0.999$ & 40 & 115 & 1.44 & $1.00-2.06$ \\
${ }^{\mathrm{d}} 0.0050$ & 0.264 & 0.732 & 0.997 & $>0.999$ & 50 & 139 & 1.39 & $1.01-1.92$ \\
${ }^{\mathrm{e}} 0.01$ & 0.479 & 0.949 & $>0.999$ & $>0.999$ & 99 & 251 & 1.27 & $1.01-1.60$ \\
\hline
\end{tabular}

*Power calculated based on a 1-sided 0.025-level log-rank test comparing the rate of severe COVID-19 disease in vaccine vs. placebo groups; participants were followed for an average of 12 months with $2 \%$ annual dropout; all events post enrollment were counted. **The five placebo arm incidence scenarios correspond to: (a) 2\% annual COVID-19 incidence and 5\% severe cases; (b) 4\% annual COVID-19 incidence and 5\% severe cases; (c) 4\% annual COVID-19 incidence and 10\% severe cases; (d) 2\% annual COVID-19 incidence and 25\% severe cases; (e) 4\% annual COVID-19 incidence and 25\% severe cases.

***Expected numbers of observed placebo group cases of severe COVID-19 disease (Expected \# Placebo Cases) are calculated based on the incidence assumed in the first column, with $2 \%$ annual dropout. Estimated (Est.) hazard ratio (HR) is the smallest estimated HR of severe COVID-19 disease (vaccine/placebo) such that the Wald 2-sided 95\% confidence interval (CI) in a Cox proportional hazards model just lies above 1.0, where \# Vaccine Cases and 95\% CI correspond to this estimate. 